\title{
A map analysis of patterned-ground along a North American Arctic Transect
}

\author{
Martha K. Raynolds, ${ }^{1}$ Donald A. Walker, ${ }^{1}$ Corinne A. Munger, ${ }^{1}$ \\ Corinne M. Vonlanthen, ${ }^{2}$ and Anja N. Kade ${ }^{1}$ \\ Received 4 June 2007; revised 7 January 2008; accepted 4 February 2008; published 4 June 2008.
}

[1] Arctic patterned-ground features have been described individually, but never examined as parts of integrated landscape/ecosystems that vary along the Arctic climate gradient. Here we examine the complex interrelationships between patterned ground, climate, vegetation and soil along a north-south transect through all five bioclimate subzones of the North American Arctic. We mapped the vegetation, biomass, end-of-summer thaw depths, and snow cover on twenty $10 \times 10$-m grids. The vegetation maps illustrate the transition of vegetation types and patterns from north to south. Biomass maps showed lower biomass in the centers of patterned-ground features than in areas between features, and increasing biomass from north to south. Thaw-depth maps showed deeper thaw in the centers of features than between features, and shallow thaw on the north and south ends of the transect. Snow depth maps showed less snow on patterned-ground features subject to differential frost heave compared to areas between features which did not heave, and a north-south gradient of increasing snow depth. The maps also documented the change from small nonsorted polygons to larger nonsorted circles from north to south, and increasing pattern size with moisture. Principal components analysis revealed underlying relationships between patterned-ground landscapes and measured vegetation and environmental variables. Climate in combination with the vegetation was the most important factor affecting patterned ground on zonal sites, but soil moisture, texture and chemistry were also important.

Citation: Raynolds, M. K., D. A. Walker, C. A. Munger, C. M. Vonlanthen, and A. N. Kade (2008), A map analysis of patternedground along a North American Arctic Transect, J. Geophys. Res., 113, G03S03, doi:10.1029/2007JG000512.

\section{Introduction}

[2] The Arctic tundra bioclimate zone is the area north of the latitudinal limit of trees (Figure 1). It is characterized by low-growing plants and a cold climate, but it is far from uniform. Vegetation across the Arctic climate gradient ranges from lichen- and moss-dominated barrens in the north, to dense shrub thickets in the south. At the scale of 1 to $10 \mathrm{~m}$, Arctic landscapes exhibit a large amount of heterogeneity that is caused by patterned-ground features (Figure 2), including polygons, circles, and hummocks. The genesis of these features is related to a variety of cryogenic processes, including but not limited to frost heave, frost cracking, frost sorting, and gelifluction [Washburn, 1980]. On flat surfaces with fine-grained soils and no rocks, these processes result in nonsorted features, including nonsorted polygons, nonsorted circles, and hummocks. The full range of patterned-ground features that includes sorted forms in coarse-textured soils and features on slopes has been described by Washburn [1980]. In this paper we follow

\footnotetext{
${ }^{1}$ Institute of Arctic Biology, University of Alaska Fairbanks, Fairbanks, Alaska, USA

${ }^{2}$ Plant Science Center, ETH Zurich, Zurich, Switzerland.

Copyright 2008 by the American Geophysical Union. 0148-0227/08/2007JG000512\$09.00
}

Washburn's [1980] terminology with some modification (Table 1, see Methods section for a more complete explanation of each patterned-ground type).

[3] This study mapped small-scale patterned-ground features, focusing on those that occurred on zonal soils within each bioclimate subzone (Figures 1 and 2). Mapped data included patterned-ground type, vegetation type, biomass, thaw depth, and snow depth. The goal was to document trends in patterned-ground landscapes along the Arctic climate gradient, and to better understand how a variety of environmental influences affect this patterning.

[4] Mapping of arctic vegetation at a similar detailed scale has been done by Matveyeva [1998] on the Taimyr Peninsula and by Walker [1972] at Barrow, Alaska. This study was carried out along a North American Arctic Transect (Figure 1), where climate, permafrost, and ecosystems characteristics were sampled and monitored as part of the Biocomplexity of Patterned Ground Ecosystems project [Walker et al., 2004]. Other aspects of this project are presented in additional articles in this journal. The data sets produced by this project document conditions at permanent plots that can be revisited in the future to investigate the effects of climate change. The data form a legacy data set for the International Polar Year [National_Research_Council, 2004] (http://www.ipy.org), and contribute to the Circumpo- 


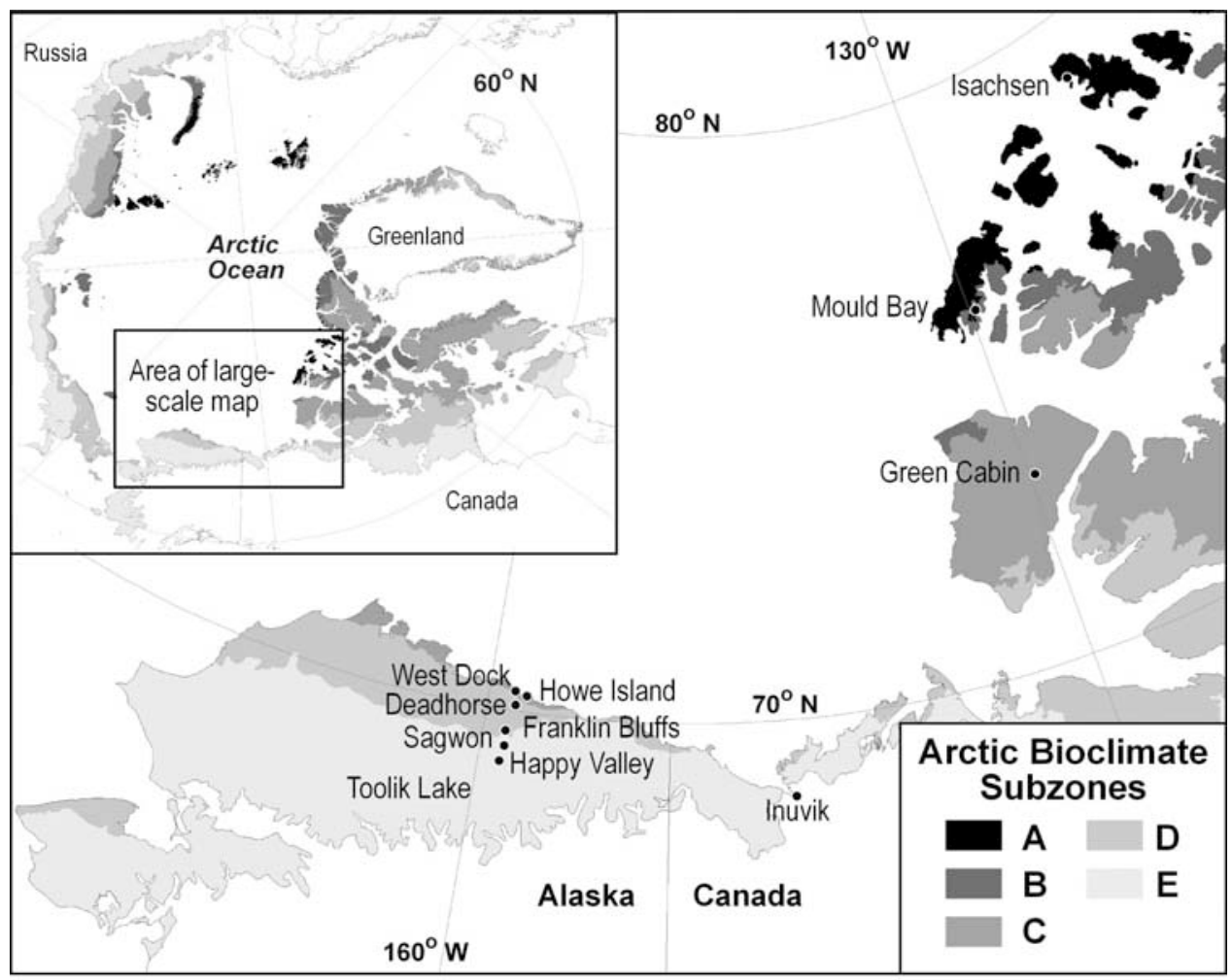

Figure 1. Map of study locations along the North American Arctic Transect. Arctic bioclimate subzones mapped according to the Circumpolar Arctic Vegetation Map [CAVM Team, 2003].

lar Active Layer Monitoring program (CALM) [Brown et al., 2000] (http://www.udel.edu/Geography/calm).

\section{Methods}

\subsection{Climate Gradient}

[5] The Arctic is divided into five bioclimate subzones (A-E, cold to warm), each with its own climate and distinctive vegetation [CAVM Team, 2003; Elvebakk, 1999]. We characterized the growing season of the bioclimate subzones using Summer Warmth Index (SWI, sum of monthly mean air temperature $>0{ }^{\circ} \mathrm{C}$ ). Subzone A (SWI < $6^{\circ} \mathrm{C}$ ) is sparsely vegetated, with no shrubs or sedges. Subzone B (SWI 6-9 ${ }^{\circ} \mathrm{C}$ ) is characterized by greater cover of plants, which include prostrate dwarf-shrubs and sedges. Subzone C (SWI $9-12^{\circ} \mathrm{C}$ ) has mostly complete plant cover, and hemi-prostrate shrubs up to $15 \mathrm{~cm}$ tall commonly occur, especially in snowbeds. Subzone D (SWI $12-20^{\circ} \mathrm{C}$ ) is almost completely vegetated, and dwarf shrubs up to $40 \mathrm{~cm}$ tall occur. Subzone E (SWI $20-35^{\circ} \mathrm{C}$ ) has very little bare ground. Shrubs are commonly $20-50 \mathrm{~cm}$ tall, and can reach up to $2 \mathrm{~m}$ in protected areas along streams. A more complete description of the typical vegetation found in each subzone is in Walker et al. [2005].

\subsection{Study Locations and Grids}

[6] Ten study locations were chosen along the arctic bioclimate gradient, including at least one location in each of the five Arctic Bioclimate Subzones (Figure 1 and Table 2). The northern portion of the gradient (Subzones A, B, C) was studied at three locations in the western Canadian Arctic Islands: Isachsen on Ellef Ringnes Island, Nunavut (Subzone A);
Mould Bay on Prince Patrick Island, N.W.T. (Subzone B); and Green Cabin on Banks Island, N.W.T. (Subzone C). The southern end of the gradient was studied at seven locations along the Dalton Highway on the North Slope of Alaska: Howe Island and West Dock (Subzone C), Deadhorse, Franklin Bluffs, and Sagwon Nonacidic Tundra (Subzone D), and Sagwon Acidic Tundra and Happy Valley (Subzone E).

[7] At each location, we determined the zonal vegetation of the area, defined as areas that were typical of the local vegetation, with fine-grained soils, and no extremes of moisture, slope, soil chemistry or disturbance [Razzhivin, 1999]. We set up a $10 \times 10$-m grid in this zonal vegetation, marked the corners with 1.2-m tall plastic pipe, and marked each meter within the grid with pin flags (Figure 2). In areas with a range of moisture conditions, we set up grids in drier and wetter sites as well. Two grids were established at the Sagwon Nonacidic Tundra location to capture the variation in the patterning in this transitional area between Subzones $\mathrm{D}$ and $\mathrm{E}$.

\subsection{Patterned-Ground Types}

[8] Characteristic patterned-ground features found along the North American Transect include polygons, hummocks, and circles [Washburn, 1980]. A brief description of the types we mapped follows. We discuss only nonsorted patterned-ground features, i.e., features occurring in fine grained soils without gravel or stones, and only features that occur on relatively flat surfaces.

\subsubsection{Polygons}

[9] Polygons are features with linear boundaries, separated from each other by contraction cracks. Small 


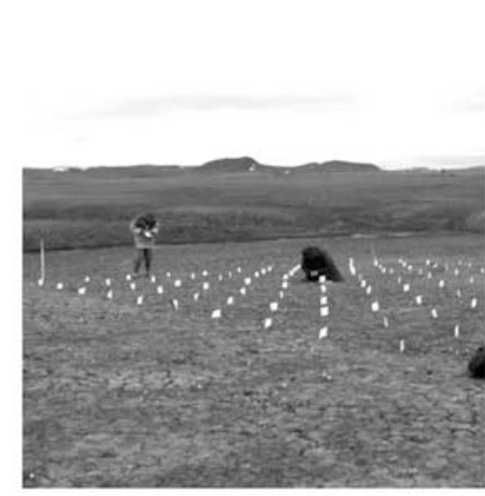

A

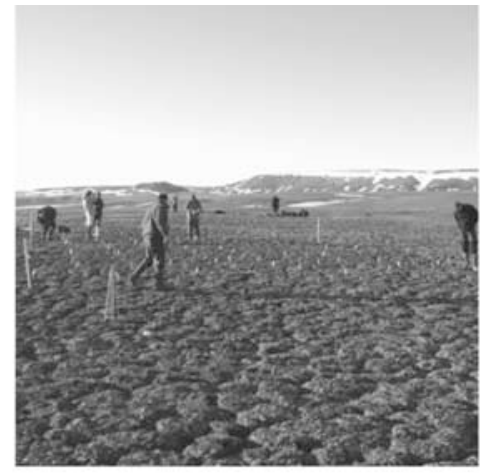

B

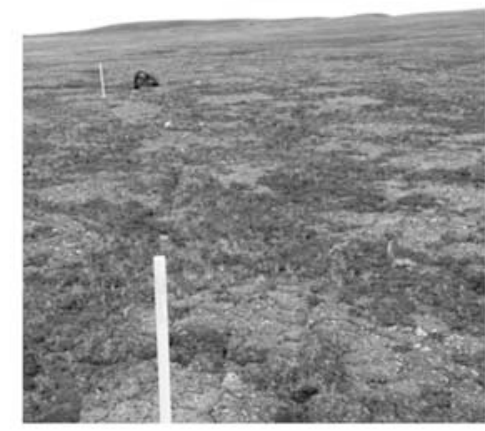

C

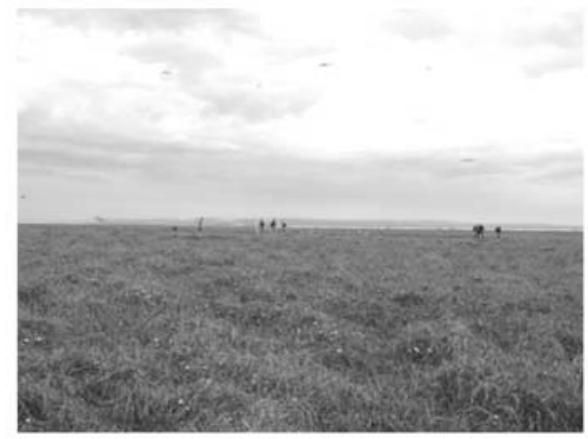

D

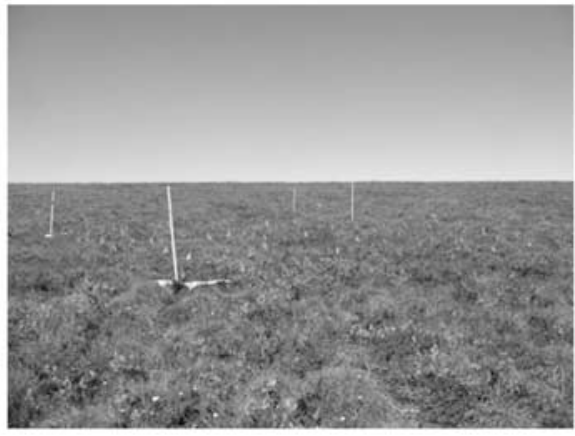

E

Figure 2. Photos of $10 \times 10-\mathrm{m}$ grids on zonal vegetation in each of the Arctic Bioclimate Subzones: A: Isachsen, Ellef Ringnes Island, Nunavut; B: Mould Bay, Prince Patrick Island, N.W.T.; C: Green Cabin, Banks Island, N.W.T.; D: Franklin Bluffs, North Slope, Alaska; E: Happy Valley, North Slope, Alaska. (photos by D.A. Walker)

nonsorted polygons $(10-30 \mathrm{~cm}$ diameter, Figure 3a) are often nearly totally barren. Plants are generally confined to the narrow cracks between polygons. These were the most common patterned-ground features on sites within Subzone A. In Subzone B the edges of the polygons were usually more vegetated. The genesis of these features has been most commonly attributed to desiccation cracking, but seasonal frost cracking (thermal cracking that is confined to the active layer) may also be involved [Washburn, 1980]. Medium-size nonsorted polygons (30-200-cm diameter, Figure $3 b$ ) occurred in more favorable (warmer, moister) microsites of Subzone A, and in Subzones B and C. These features are aggregations of small nonsorted polygons, forming larger polygons. The processes involved in the formation of these features are not fully understood, but they are likely the result of a complex combination of processes, as has been shown in the formation of small, sorted polygons in nonpermafrost regions [Ballantyne, 1996].

[10] Large nonsorted polygons (10-30 $\mathrm{m}$ diameter) also occurred at several of the mapped sites but we did not consider them in this analysis because the scale of these features was too large for the $10-\mathrm{m}$ grids used in our study. These features are the result of thermal contraction cracking deep into the

Table 1. Zonal Patterned-Ground Features Mapped Along a North American Arctic Transect

\begin{tabular}{llll}
\hline \multicolumn{1}{c}{ Feature } & \multicolumn{1}{c}{ Definition } & Subtype & \multicolumn{1}{c}{ Typical Dimensions } \\
\hline Nonsorted Polygons & Polygonal forms without a border of stones, & Small & $10-30 \mathrm{~cm}$ diam. \\
& delineated by a crack or trough between adjacent polygons & Medium & $30-200 \mathrm{~cm}$ diam. \\
Nonsorted Circles & Circular forms without a border of stones. & Small & $10-50 \mathrm{~cm}$ diam. \\
& Less vegetated in centers, and more vegetated on margins & Medium & $50-200 \mathrm{~cm}$ diam. \\
& (synonyms include mud boils, frost boils, frost medallions, & Large & $>200 \mathrm{~cm} \mathrm{diam.}$ \\
& spotted tundra) & Small & $15-30 \mathrm{~cm} \mathrm{diam.} 10-20 \mathrm{~cm} \mathrm{high}$ \\
Hummocks & $\begin{array}{c}\text { Dome-shaped features with a raised center and depression or } \\
\text { trough between hummocks }\end{array}$ & Medium & $100-200 \mathrm{~cm} \mathrm{diam.} 30-60 \mathrm{~cm}$ high \\
\hline
\end{tabular}




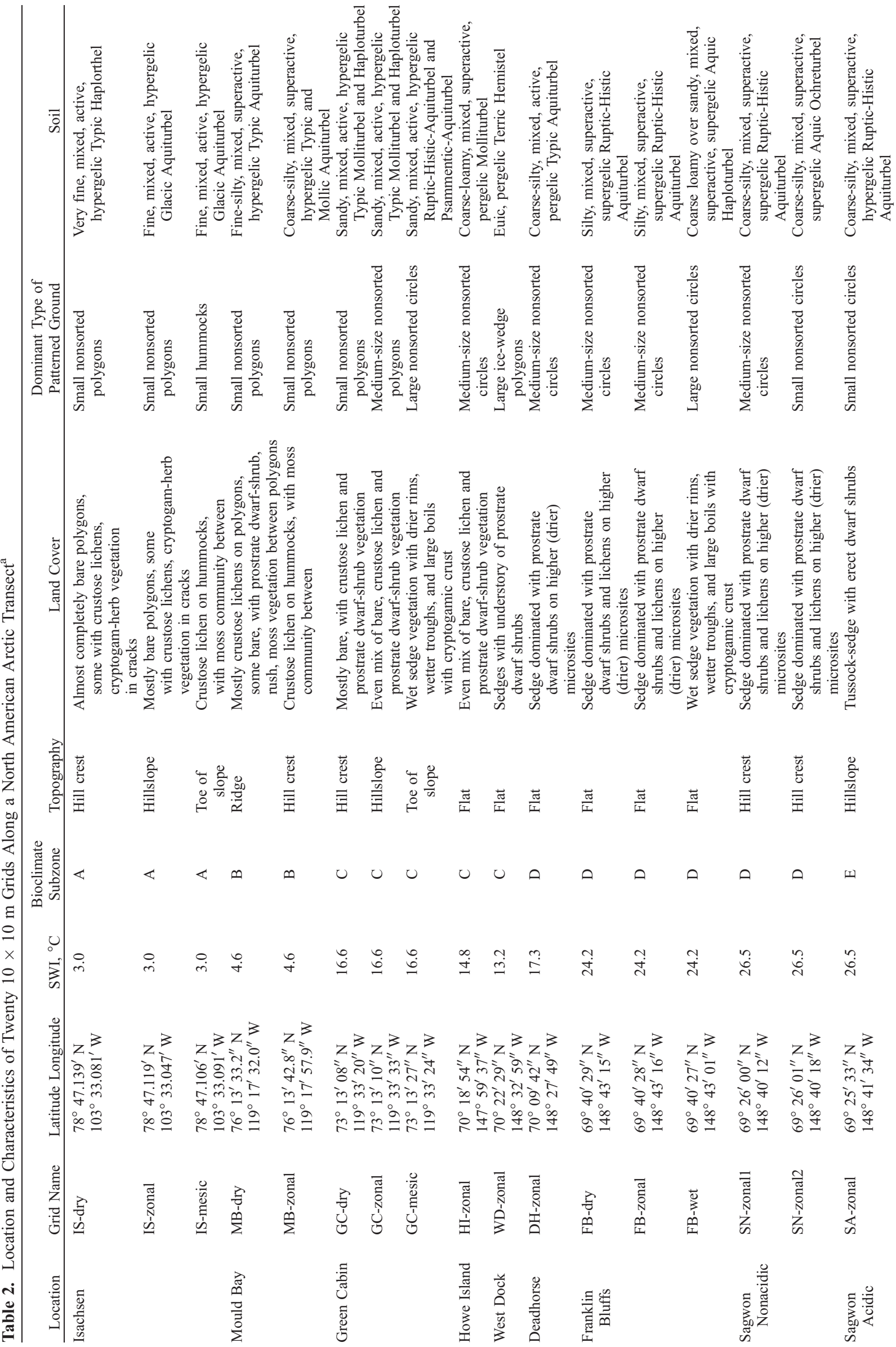


permafrost. The processes involved in the genesis of large icewedge polygons are relatively well understood and described mathematically [Lachenbruch, 1962].

\subsubsection{Circles}

[11] Nonsorted circles are dominantly circular or elliptical features and are characteristically bare or partially vegetated in their centers, and completely vegetated on their margins. Synonyms include mud boils, frost boils, frost medallions, spotted tundra. Small nonsorted circles $(<50 \mathrm{~cm}$ diameter, Figure 3c) were found commonly in Subzone E between Eriophorum vaginatum tussocks or at the edges of lichen areas in tussock tundra landscapes, and are likely the remnants of medium-size nonsorted circles that have been colonized by vegetation from the sides. Medium-size nonsorted circles $(50-200 \mathrm{~cm}$ diameter, Figure 3d) have centers that are often barren or partially vegetated. Large nonsorted circles (2-3 m diameter, Figure $3 \mathrm{e}$ ) occur in wetter sites and are sometimes surrounded by a raised ring with somewhat drier vegetation. Nonsorted circles are thought to be primarily the product of differential frost heave [Washburn, 1980; Peterson and Krantz, 2003].

\subsubsection{Hummocks}

[12] Hummocks are characterized by their elevated surface micro-relief. Small hummocks $(10-20 \mathrm{~cm}$ high and $15-30 \mathrm{~cm}$ in diameter, Figure $3 \mathrm{f}$ ) are dome-shaped features that are mostly vegetated, with one plant community on the hummocks, and a different plant community between the hummocks. The tops of the hummocks sometimes have eroded bare patches. Small hummocks are most common on slopes in snow accumulation areas in Subzones $\mathrm{A}, \mathrm{B}$ and $\mathrm{C}$, and are thought to be small nonsorted polygons that have been modified by fluvial erosion of the troughs and aeolian deposition on the tops of the hummocks [Broll and Tarnocai, 2002]. Medium-size hummocks (1-2 m in diameter and about $30-60 \mathrm{~cm}$ in height, Figure $3 \mathrm{~g}$ ) are completely vegetated features, and are modifications of nonsorted circles produced by ice aggradation, as has been described recently by Kokelj et al. [2007] and Shur and Jorgenson [2007].

[13] More than one type of patterned ground features can occur at a site. For example, at Howe Island, there are four different scales of patterning (Figure 3h). At the smallest scale are the dry, barren small nonsorted polygons. These are in the centers of medium-size nonsorted circles, whose edges are a ring of small nonsorted polygons vegetated by a dark cryptogamic crust. The circles give the landscape its pock-marked appearance. Each circle occurs within a medium-size nonsorted polygon, whose cracks are vegetated by dwarf shrubs, forbs and mosses. Groups of these polygons in turn form large nonsorted ice-wedge polygons.

\subsection{Vegetation Maps}

[14] We mapped the vegetation of the $10 \times 10$-m grids by hand in the field. We first evaluated and subjectively defined the major plant communities, then drew contours on gridded paper around areas of relatively homogeneous vegetation, using the grid points to guide the delimitation of the boundaries. We also mapped a characteristic $1 \times 1-\mathrm{m}$ quadrat within each of the zonal grids to capture the spatial interaction of finer-scale features not possible to draw at the $10-\mathrm{m}$ scale. For the $1-\mathrm{m}$ maps, we used a metal $1 \times 1-\mathrm{m}$ frame with strings every $10 \mathrm{~cm}$ to guide the mapping. The 
a)

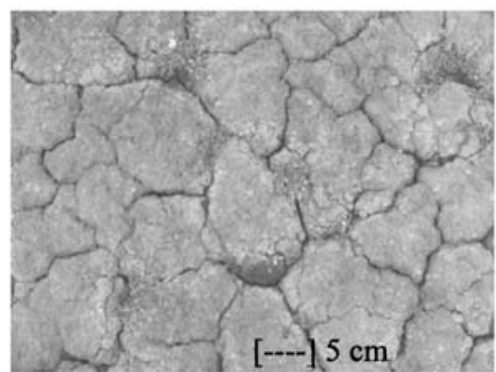

c)

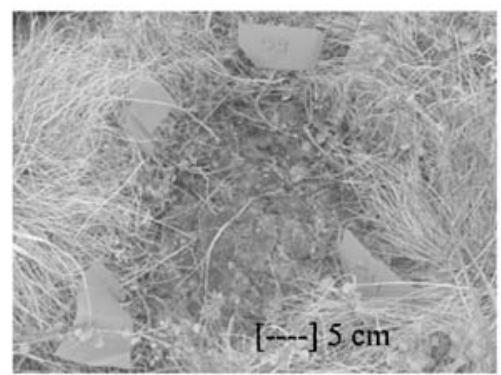

e)

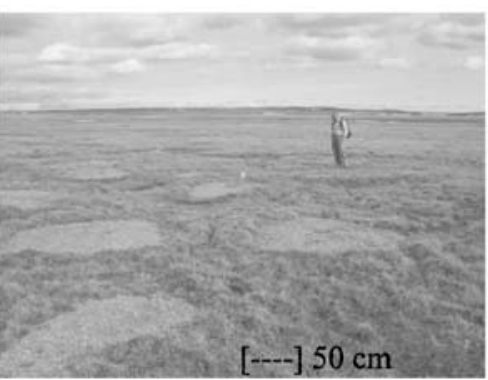

g)

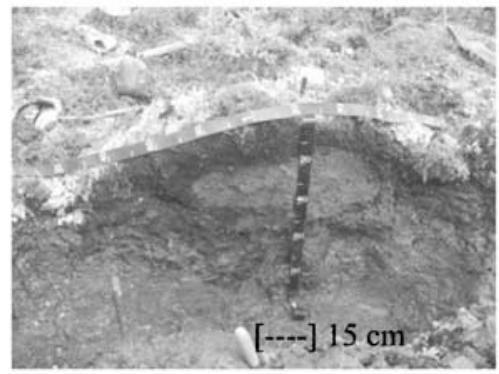

b)

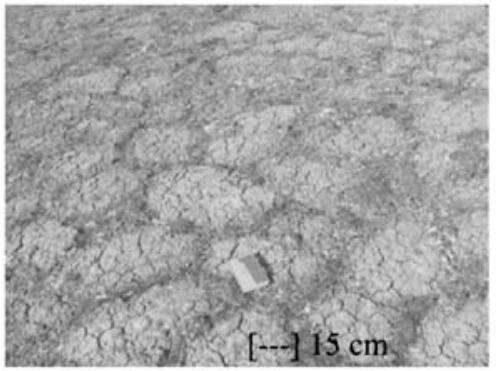

d)

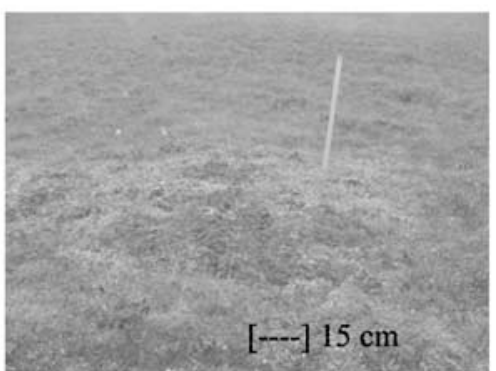

f)

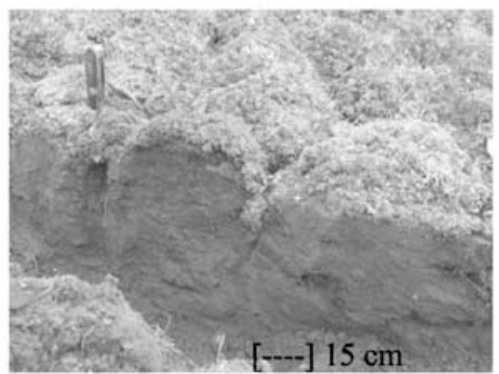

h)

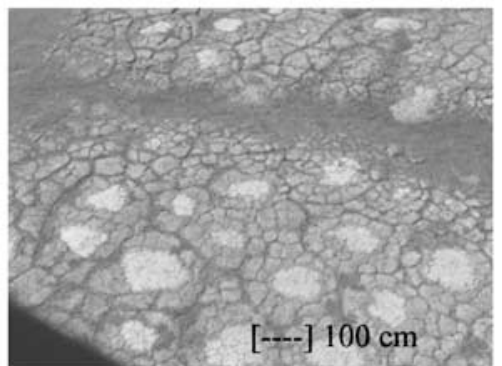

Figure 3. Photos of common patterned-ground features: (a) small nonsorted polygons, (b) medium-size nonsorted polygons, (c) small nonsorted circle, (d) medium-size nonsorted circle, (e) large nonsorted circles, (f) small hummocks, (g) medium-size hummock, (h) aerial photo of Howe Island, AK showing multiple scales of patterning (photos by D. A. Walker).

hand-drawn maps were later digitized for area analysis. The plant communities were sampled and described from plots adjacent to the grids, according to the Braun-Blanquet approach [Kade et al., 2005; Vonlanthen et al., 2008]. The map units from all 20 grids were grouped into physiognomic units based on the Circumpolar Arctic Vegetation Map (CAVM) [CAVM Team, 2003] to provide consistent units and colors across the 20 maps for this presentation. In Subzones A and B, patterning of the zonal sites was too detailed to map at the full $10 \times 10-\mathrm{m}$ scale, so $5 \times 5-\mathrm{m}$ areas were mapped. In Figure 4, the maps were reproduced four times to represent a $10 \times 10$-m area, matching the other maps. One zonal grid from each bioclimate subzone, and a dry and wet grid from Subzone D were chosen for inclusion in Figure 4. Maps of the other grids are in Figure S1 (available as auxiliary material). ${ }^{1}$

\subsection{Thaw Depths and Snow Maps}

[15] The depth of the thawed soil layer above permafrost varies seasonally and between years. It was measured at $0.5 \mathrm{~m}$ or $1.0 \mathrm{~m}$ spacing within the grids, using a metal probe [Molau and Molgaard, 1996]. Snow depth was measured at $1.0 \mathrm{~m}$ spacing, also using a metal probe. Thaw depths were measured when the grids were established (mid-July, 20012005) and at the end of the growing season for all plots (mid-August 2006). Snow depths were collected at the end

\footnotetext{
${ }^{1}$ Auxiliary materials are available in the HTML. doi:10.1029/ 2007JG000512.
} 

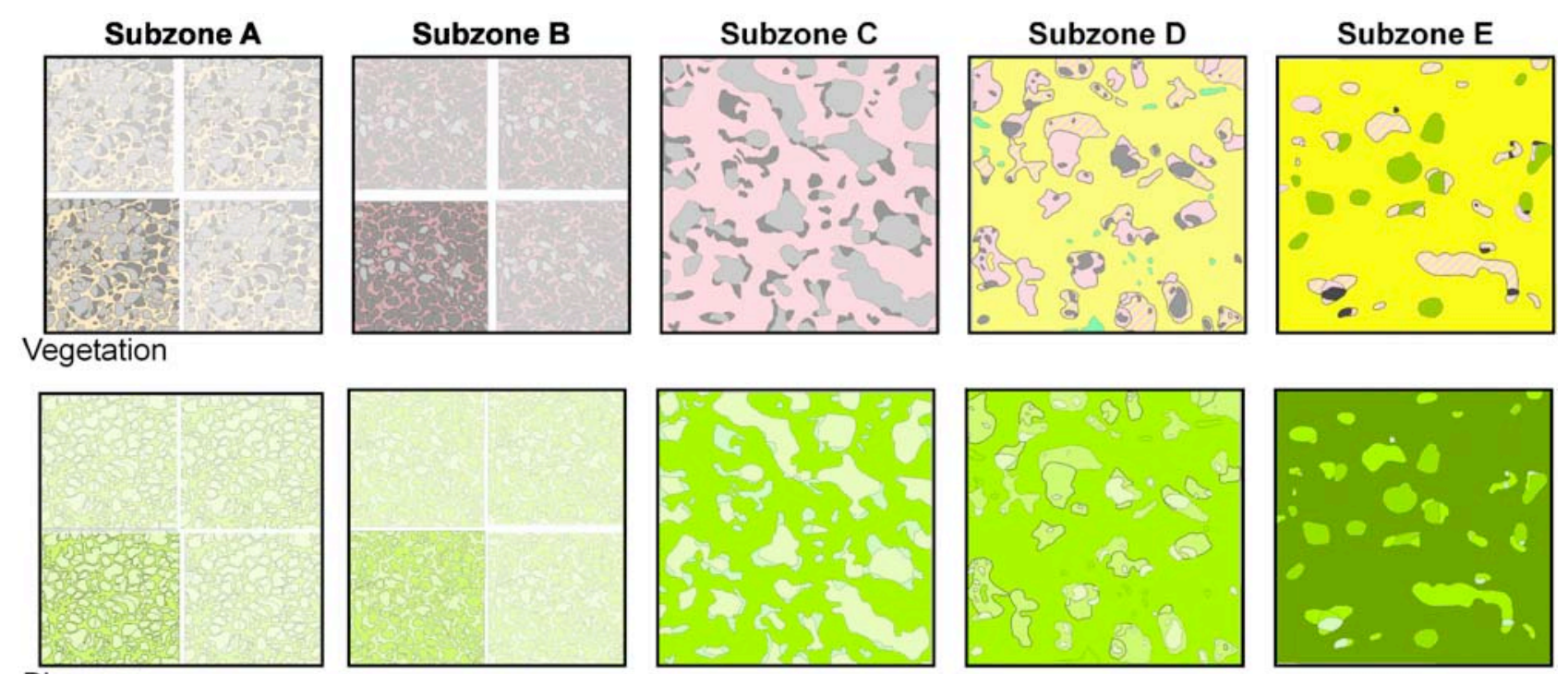

\section{Biomass}
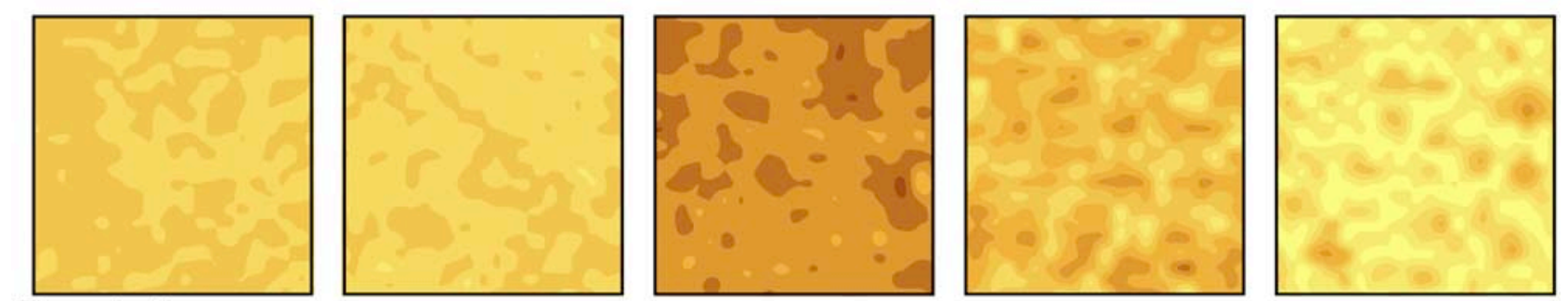

Thaw depth
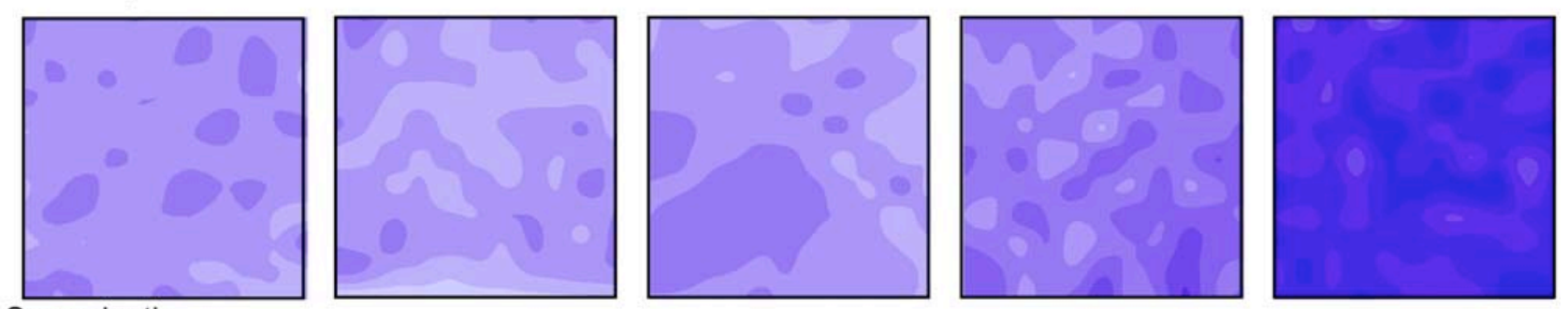

Snow depth

Figure 4. Maps of vegetation, biomass, mid-July thaw depth, and end-of-season snow depth on $10 \times 10-\mathrm{m}$ grids in Tundra Bioclimate Subzones A-E (is-z, mb-z, gc-z, fb-z, hv-z respectively, except subzone $\mathrm{C}$ snow which is from wd-z). Maps of $5 \times 5 \mathrm{~m}$ for vegetation and biomass of Subzones $\mathrm{A}$ and B were duplicated (grayed-out portion) to fill the $10 \times 10-\mathrm{m}$. See Figure 5 for legend and Table 2 for description of vegetation communities in each grid.

of winter, before the beginning of spring melt. Snow data were not collected at Green Cabin grids because it was not possible to land at the site in May 2006 when snow data were collected from the other Canadian Arctic Islands locations. However, a sonic snow measuring device recorded the snow depth near the zonal grid on a similar flat site and these data were used as an estimate of snow depth on the grid. Sites which were easier to access (those along the Dalton Highway in Alaska) were measured repeatedly, at different times of year, during multiple years. Maps of thaw and snow data were created by interpolating between the data points using GIS software.

\subsection{Biomass, Soil, and Environmental Data}

[16] Five study plots were chosen near the grids to characterize each plant community type that occurred on the grid. One aboveground biomass sample was clipped from each of these plots at the time of peak biomass, using a $20 \times 50-\mathrm{cm}$ quadrat. The samples were frozen, then later sorted according to plant functional types, dried and weighed. These biomass values were then applied to the vegetation maps to create maps representing the distribution of biomass on the grids. See Walker et al. [2008] for more details on the biomass sampling methods and results. Soil samples were collected from the upper $10 \mathrm{~cm}$ of the mineral horizon, and analyzed for moisture content, texture, and chemistry [Kade et al., 2005]. The depth of soil horizons was measured. Environmental characteristics, including vegetation height, moss height, and surface microrelief, were recorded for each plot. Climate characteristic including mean annual air temperature, summer warmth index, mean annual surface temperature, and mean annual permafrost temperature at $0.8 \mathrm{~m}$ were collected from an automatic 


\section{Vegetation of $10 \times 10 \mathrm{~m}$ grids}
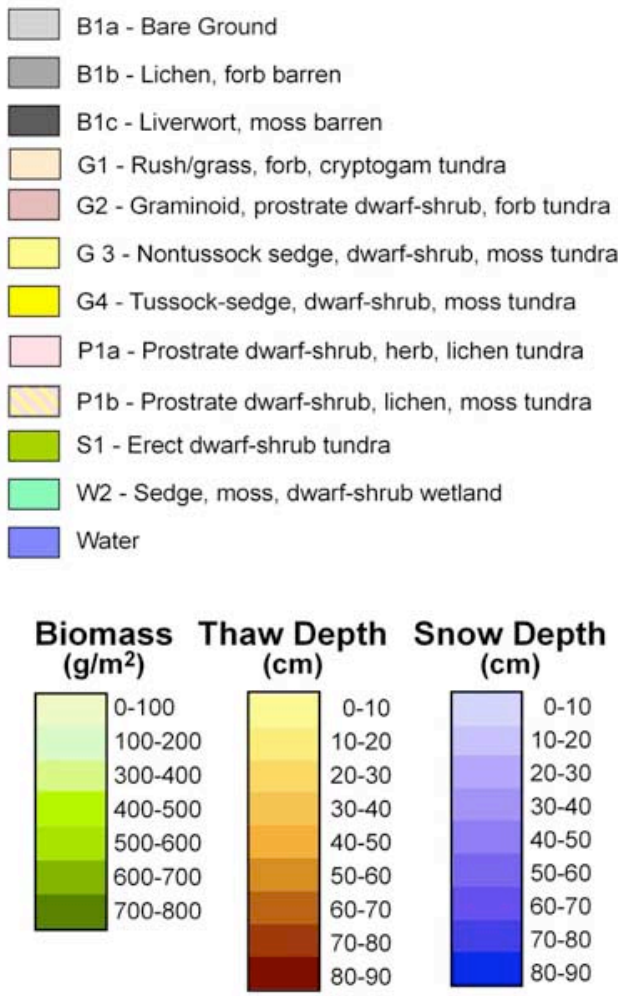

Figure 5. Legend of vegetation types, biomass, activelayer depth and snow depth mapped on grids.

climate station located near the grids (one station per location).

\subsection{Analysis}

[17] Mean thaw depth and snow depth for each mapped vegetation unit on the five zonal $10 \times 10$ m-grids was calculated. Interpolated thaw-depth and snow-depth maps were compared with the vegetation map units using GIS software, and a mean thaw depth and a mean snow depth were determined for each vegetation type. Significance of the difference in mean snow depth and thaw depth among vegetation units was determined using t-tests with Bonferroni's correction for multiple tests.

[18] We used principal components analysis (PCA) [McCune and Grace, 2002] to determine which environ- mental and vegetation data best explained the observed differences between the sites. Principal components analysis is a data reduction method used to extract relevant information from complex multivariant data sets. The goal of PCA is to reduce the original set of variables, many of which may be highly correlated with each other, to a fewer number of variables (or components) that are not correlated with each other. The first component (or axis) of PCA is the one that explains the maximum amount of variation in a data set, and successive components explain lesser amounts of the variation. The strength of the correlations ( $r^{2}$ values) between the original set of variables and each component can be used to determine which of the variables most strongly influence each component. We used a matrix consisting of the 20 grids and 46 environmental variables that characterized the grids. Some of the data were collected directly on the grids (such as snow depth and thaw depth), and some from the plant community plots adjacent to the grids. The plot data were used to calculate weighted averages for the grid, based on the cover of the plant communities within the grid. To help visualize the relationships between the grids and the environmental factors, we used PC-Ord [McCune and Mefford, 1999] to graph the 20 grids within an ordination space defined by the first two components of the PCA. We also ran an ordination exploring how well the environmental variables explained the variation in biomass of plant functional types on each grid.

\section{Results}

\subsection{Patterned Ground Types}

[19] The types of patterned ground on zonal sites varied along the climate gradient, with decreasing bare ground and increasing pattern size with warmer conditions (Figures 4 and 6). Small nonsorted polygons were the dominant patterned ground form in Subzone A. These polygons were mostly barren, with only scattered plants. Most of the vegetation occurred in the cracks, in some cases forming a net of vegetation and aggregating the small polygons into larger ones (Figures $3 \mathrm{~b}$ and 6 ). The unvegetated cracks were too fine to be mapped on the $10 \times 10-\mathrm{m}$ scale, but are shown on the $1 \times 1-\mathrm{m}$ map. Patterns in Subzone B were caused by well-vegetated small nonsorted polygons. Welldeveloped mats of mosses, lichens, and small vascular plants occurred in the cracks between the polygons. In Subzone C, small nonsorted polygons were aggregated into medium-size nonsorted polygons $1-2 \mathrm{~m}$ in diameter (Figure 6), and the inter-polygon areas had a well-developed

\section{Subzone A}

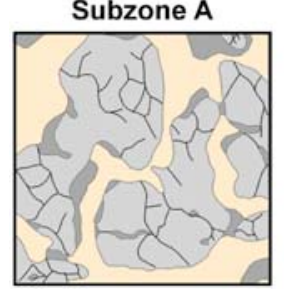

Subzone B

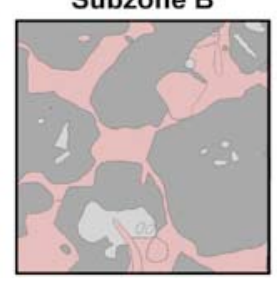

Subzone C

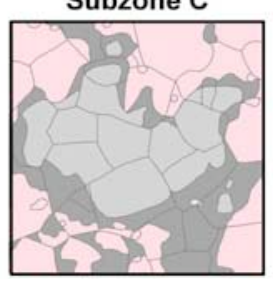

Subzone D

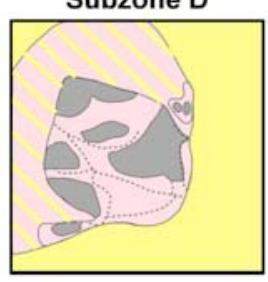

Subzone E

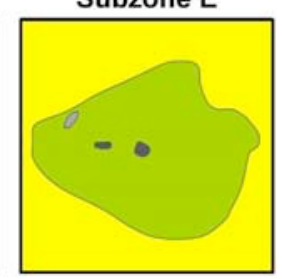

Figure 6. Detailed $1 \times 1-\mathrm{m}$ grid maps within zonal $10 \times 10$-m grids in tundra bioclimate subzones A-E (is-z, mb-z, gc-z, fb-z and hv-z respectively). See Figure 5 for legend. 


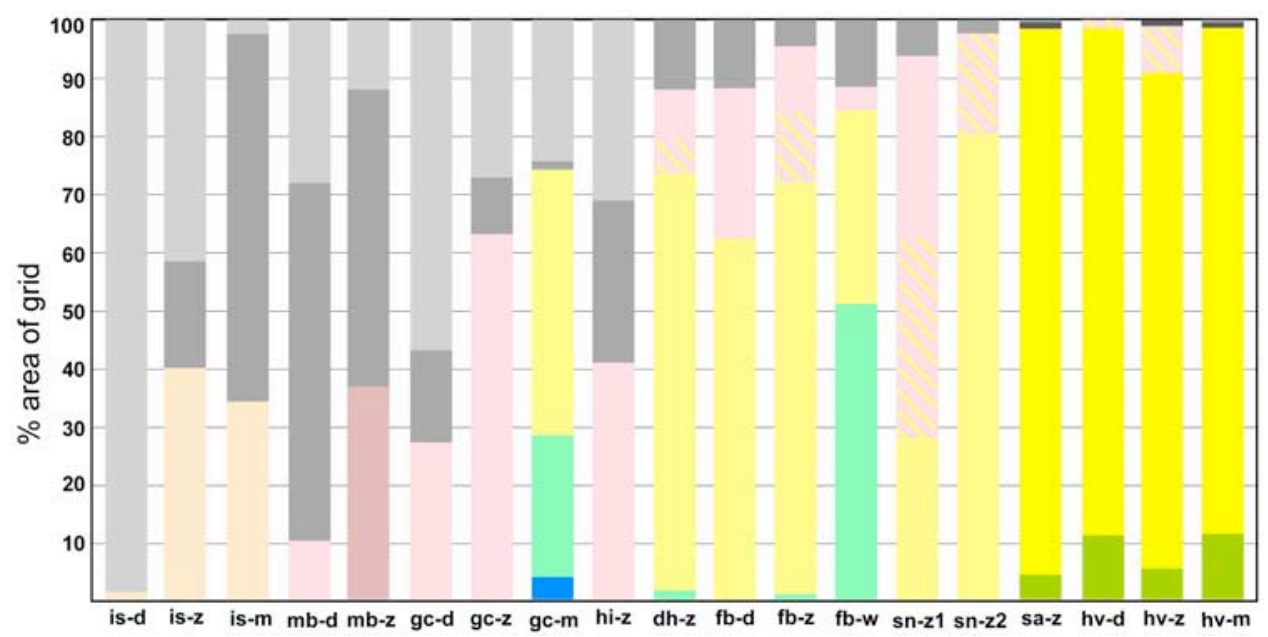

Figure 7. Proportion of area of vegetation types for the $10 \times 10-\mathrm{m}$ grids. See Figure 5 for legend.

plant community (Figure 4). In Subzone D, the prominent patterned-ground features were nonsorted circles, about $1.5 \mathrm{~m}$ in diameter, which were less vegetated than the surrounding areas. The vegetation between the circles often included a thick moss carpet. Subzone E had variations in vegetation that indicated relict nonsorted circles, including small $(<15 \mathrm{~cm}$ diameter) bare patches between tussocks, lichenrich patches and medium-size hummocks dominated by ericaceous shrubs and lichens.

\subsection{Vegetation}

[20] The vegetation of the grids changed from north to south, from cryptogam-dominated communities to prostrate-shrub to sedge, dwarf-shrub communities. Bare ground decreased in extent, and in Subzones C, D and E was rarely completely bare, covered at least by a cryptogamic crust. In Subzone A at Isachsen, rush/grass, forb, cryptogam tundra occurred in areas along contractions cracks between small nonsorted polygons, and covered $40 \%$ of the zonal grid (Figures 4 and 7). This Saxifrago-Parmelia omphalodes ssp. glacialis community (Vonlanthen et al., 2008) covered less of the dry grid (is-d, Table 3). A different community, Aulacomnium turgidum -Racomitrium ericoides formed the rush/grass, forb, cryptogam tundra between the small hummocks on the mesic grid (is-m). The other common vegetation communities were lichen-forb barrens with scattered vascular plants, which covered $>18 \%$ of the zonal grid, and most of the hummocks on the moister grid. Over $40 \%$ of the zonal grid was bare ground, with no macro-vegetation, though small patches of lichen crusts were common. This was the case for $99 \%$ of the drier grid.

[21] In Subzone B at Mould Bay, lichen, forb barrens were common on the dry grid (mb-d), and covered over $50 \%$ of the zonal grid, occurring on small nonsorted polygons. Graminoid, prostrate dwarf-shrub, forb tundra covered over one third of the zonal grid, growing between the polygons. In Subzone C, vegetation types were similar to those in Subzone B, though plant community composition varied (Table 3), and the amount of bare ground decreased (Figure 7). On the zonal grid at Green Cabin,
$63 \%$ of the vegetation was prostrate, dwarf-shrub, herb tundra, growing from the edges of medium-size nonsorted polygons. Wetter conditions at the toe of a slope (gc-m), supported nontussock sedge, dwarf-shrub, moss tundra, with sedge, moss, dwarf-shrub wetland in the wettest microsites between large bare nonsorted circles. West Dock, which had no small patterned ground features, was $100 \%$ nontussock sedge, dwarf-shrub, moss tundra.

[22] In Subzone D, nontussock sedge, dwarf- shrub, moss tundra was the most common vegetation type, covering over $70 \%$ of the zonal grid at Franklin Bluffs (Figure 7). Vegetation types of patterned-ground features covered the other $30 \%$. Lichen, forb barren occurred on the driest, most disturbed areas in the centers of the nonsorted circles, and prostrate dwarf-shrub, herb tundra grew on their edges. Some of this Junco biglumis-Dryadetum integrifoliae pedicularetosum community had a thick moss layer, and was mapped separately (P1b in Figures 4-7). The wet site (fb-w) was mostly sedge, moss, dwarf-shrub wetland, with some mesic vegetation similar to the other Subzone D grids described above, growing in a ring around the large nonsorted circle. In Subzone E at Sagwon and Happy Valley, the most common vegetation type was tussock-sedge, dwarf-shrub, moss tundra, which covered over $86 \%$ of the zonal grids. Erect dwarf-shrub tundra occurred on hummocks in this subzone, and the bare spots between tussocks had an Anthelia juratzkana-Juncus biglumis barren community growing on them (Table 3 ).

\subsection{Biomass}

[23] Biomass of vegetation types between patterned areas increased from $37 \mathrm{~kg} / 100 \mathrm{~m}^{2}$ in Subzone A to $76 \mathrm{~kg} / 100 \mathrm{~m}^{2}$ in Subzone E. There was much less biomass on the centers of the patterns $\left(0-15 \mathrm{~kg} / 100 \mathrm{~m}^{2}\right.$, Subzone A-E) than between the patterns $\left(30-76 \mathrm{~kg} / 100 \mathrm{~m}^{2}\right.$, Subzone A-E). The areas between the patterns occupied a very small portion of the total landscape at the northern sites, mainly cracks between nonsorted polygons, whereas in the southern Arctic the area between the patterns was the dominant component of the landscape (Figures 4 and 7). Above- 
Table 3. Plant Community Descriptions for $10 \times 10-\mathrm{m}$ Grids Along a North American Arctic Transect ${ }^{\mathrm{a}}$

\begin{tabular}{|c|c|c|}
\hline $\begin{array}{l}\text { Location, Grid, } \\
\text { Vegetation Type }\end{array}$ & Plant Community & Characteristic Species \\
\hline \multicolumn{3}{|l|}{ Subzone $A$ is-d, is-z } \\
\hline B1b & Puccinellia angustata-Papaver & Forbs (Papaver radicatum, Draba oblongata, \\
\hline Lichen, forb barren & radicatum community & $\begin{array}{l}\text { Saxifraga cernua); grasses (Puccinellia angustata/andersonii, } \\
\text { Alopecurus alpinus); crustose lichens (Rinodina terrestris, } \\
\text { Fuscopannaria praetermissa, Lecidella wulfenii, } \\
\text { Megaspora verrucosa, Megalaria jemtlandica). }\end{array}$ \\
\hline G1 & Saxifrago-Parmelia omphalodes ssp. & Forbs (Saxifraga caespitosa, S. cernua, S. nivalis.); grasses \\
\hline $\begin{array}{l}\text { Rush/grass, forb, } \\
\text { cryptogam tundra }\end{array}$ & glacialis community & $\begin{array}{l}\text { (Festuca brachyphylla, Alopecurus alpinus); mosses } \\
\text { (Racomitrium panschii, R. lanuginosum, Pohlia cruda, } \\
\text { Aulacomnium turgidum, Timmia austriaca, } \\
\text { Polytrichastrum alpinum, Hypnum revolutum); lichens } \\
\text { (Sticta arctica, Parmelia omphalodes ssp. glacialis) }\end{array}$ \\
\hline \multicolumn{3}{|l|}{ Subzone $A$ is-m } \\
\hline B1b & Polytrichum piliferum -Pertussaria & Grass (Alopecurus alpinus); mosses (Polytrichum piliferum, \\
\hline $\begin{array}{l}\text { Cryptogam, } \\
\text { forb barren }\end{array}$ & octomela community & $\begin{array}{l}\text { Polytrichastrum alpinum, Distichium capillaceum, Ditrichum } \\
\text { flexicaule); lichens (Pertussaria octomela, } \\
\text { Protopannaria pezizoides) }\end{array}$ \\
\hline G1 & Aulacomnium turgidum -Racomitrium & Grass (Alopecurus alpinus); mosses (Aulacomnium turgidum, \\
\hline $\begin{array}{l}\text { Rush/grass, forb, } \\
\text { moss tundra }\end{array}$ & ericoides community & $\begin{array}{l}\text { Racomitrium panschii, Timmia austriaca, Tomentypnum nitens, } \\
\text { Distichium capillaceum, Ditrichum flexicaule) }\end{array}$ \\
\hline \multicolumn{3}{|l|}{ Subzone B mb-d } \\
\hline B1b & Hypogymnia subobscura - Leproloma & Rush (Luzula nivalis); lichens (Hypogymnia subobscura, \\
\hline Lichen, forb barren & community & $\begin{array}{l}\text { Leproloma sp., Lecidea ramulosa, Flavocetraria cucullata, } \\
\text { Thamnolia vermicularis var. subuliformis, } \\
\text { Bryocaulon divergens) }\end{array}$ \\
\hline P1a & Dryas integrifolia-Luzula nivalis & Prostrate dwarf-shrubs (Salix arctica, Dryas integrifolia); \\
\hline $\begin{array}{l}\text { Prostrate dwarf-shrub, } \\
\text { herb lichen tundra }\end{array}$ & community & $\begin{array}{l}\text { rush (Luzula nivalis); mosses (Hypnum revolutum, } \\
\text { Sanionia uncinata, Tortula ruralis) }\end{array}$ \\
\hline \multicolumn{3}{|l|}{ Subzone B mb-z } \\
\hline B1b & Hypogymnia subobscura-Lecanora & Forb (Saxifraga oppositifolia); rush (Luzula arctica ssp. \\
\hline Lichen, forb barren & epibryon community & $\begin{array}{l}\text { arctica); mosses (Encalypta alpina, Distichium capillaceum); } \\
\text { lichens (Hypogymnia subobscura, Vulpicida tilesii, Pertusaria } \\
\text { dactylina, Ochrolechia frigida, Lecanora luteovernalis, } \\
\text { L. epibryon, Lecidea ramulosa) }\end{array}$ \\
\hline G2 & Orthotrichum speciosum-Salix arctica & Prostrate dwarf-shrubs (Salix arctica, Dryas integrifolia); forb \\
\hline $\begin{array}{l}\text { Prostrate dwarf-shrub, } \\
\text { herb, lichen tundra }\end{array}$ & community & $\begin{array}{l}\text { (Saxifraga oppositifolia,); mosses (Orthotrichum speciosum, } \\
\text { Syntrichia ruralis, Sanionia uncinata, Tomentypnum nitens); } \\
\text { lichens (Flavocetraria cucullata, Thamnolia vermicularis,). }\end{array}$ \\
\hline \multicolumn{3}{|l|}{ Subzone C gc-d, gc-z } \\
\hline B1a & Puccinellia angustata-Potentilla vahliana & Forbs (Potentilla vahliana, Artemisia campestris ssp. borealis \\
\hline Bare ground & community & $\begin{array}{l}\text { var. borealis); grasses (Puccinellia angustata, } \\
\text { Elymus sajanensis). }\end{array}$ \\
\hline B1b & Dryas integrifolia-Carex rupestris community, & Prostrate dwarf shrubs (Dryas integrifolia, Salix arctica); \\
\hline Lichen, forb barren & Psora decipiens variant & $\begin{array}{l}\text { forbs (Potentilla vahliana, Oxytropis borealis var. borealis, } \\
\text { Lesquerella arctica, Saxifraga oppositifolia, Parrya arctica,); } \\
\text { sedges (Carex rupestris,); lichens (Psora decipiens, } \\
\text { Toninia sedifolia, Lecanora epibryon, Thamnolia vermicularis, } \\
\text { Rinodina roscida, Fulgensia bracteata). }\end{array}$ \\
\hline P1a & Dryas integrifolia-Carex rupestris & Prostrate dwarf shrubs (Dryas integrifolia, Salix arctica); \\
\hline $\begin{array}{l}\text { Prostrate dwarf-shrub, } \\
\text { herb tundra }\end{array}$ & community, Dryas integrifolia variant & $\begin{array}{l}\text { forbs (Oxytropis borealis var. borealis, Lesquerella arctica, } \\
\text { Saxifraga oppositifolia, Parrya arctica,); sedges } \\
\text { (Carex rupestris,); mosses (Syntrichia ruralis, } \\
\text { Ctenidium procerrimum, Ditrichum flexicaule, } \\
\text { Distichium capillaceum); lichens (Toninia sedifolia, } \\
\text { Lecanora epibryon, Thamnolia vermicularis, } \\
\text { Rinodina roscida, Fulgensia bracteata). }\end{array}$ \\
\hline \multicolumn{3}{|l|}{ Subzone C gc-m } \\
\hline B1b & Braya glabella ssp. purpurascens-Dryas & Prostrate dwarf shrub (Dryas integrifolia); forb \\
\hline Bare ground & integrifolia community & $\begin{array}{l}\text { (Braya glabella ssp. purpurascens); } \\
\text { moss (Hymenostylium recurvirostre). }\end{array}$ \\
\hline G3 & Dryas integrifolia-Carex aquatilis & Prostrate dwarf shrubs (Dryas integrifolia, \\
\hline $\begin{array}{l}\text { Nontussock sedge, } \\
\text { dwarf-shrub, } \\
\text { moss tundra }\end{array}$ & community & $\begin{array}{l}\text { Salix arctica); forbs (Tephroseris atropurpurea } \\
\text { ssp. atropurpurea, Pedicularis langsdorfii, } \\
\text { Saxifraga oppositifolia); graminoids } \\
\text { (Carex membranacea, Eriophorum angustifolium } \\
\text { Ssp. triste, Arctagrostis latifolia, Carex aquatilis); } \\
\text { mosses (Hypnum bambergeri, Tomentypnum nitens, } \\
\text { Ditrichum flexicaule); lichens (Polyblastia sendtneri, } \\
\text { and Dactylina arctica). }\end{array}$ \\
\hline
\end{tabular}


Table 3. (continued)

\begin{tabular}{|c|c|c|}
\hline $\begin{array}{l}\text { Location, Grid, } \\
\text { Vegetation Type }\end{array}$ & Plant Community & Characteristic Species \\
\hline $\begin{array}{l}\text { W2 } \\
\text { Sedge, moss, } \\
\text { dwarf-shrub wetland }\end{array}$ & $\begin{array}{l}\text { Eriophorum angustifolium ssp. } \\
\text { triste-Carex aquatilis community }\end{array}$ & $\begin{array}{l}\text { Prostrate dwarf shrub (Salix arctica); graminoids } \\
\text { (Carex aquatilis, Eriophorum angustifolium ssp. triste, } \\
\text { Carex membranacea, Arctagrostis latifolium); forbs } \\
\text { (Pedicularis sudetica); mosses (Campylium stellatum, } \\
\text { Hypnum bambergeri, Pseudocalliergon turgescens, } \\
\text { Meesia longiseta, Amblystegium longicuspis, Limprichtia cossonii, } \\
\text { Bryum subneodamense, Pseudocalliergon brevifolium). }\end{array}$ \\
\hline \multicolumn{3}{|r|}{ - } \\
\hline $\begin{array}{l}\text { B1b } \\
\text { Lichen, forb barren }\end{array}$ & $\begin{array}{l}\text { Mycobilimbia lobulata - Polyblastia } \\
\text { sendtneri community }\end{array}$ & $\begin{array}{l}\text { Forb (Braya glabella spp. purpurascens); crustose lichens } \\
\text { (Mycobilimbia lobulata, Polyblastia sendtneri, P. bryophila, } \\
\text { Lecanora epibryon) }\end{array}$ \\
\hline $\begin{array}{l}\text { P1a } \\
\text { Prostrate dwarf-shrub, } \\
\text { herb, lichen tundra }\end{array}$ & $\begin{array}{l}\text { Dryas integrifolium - Salix ovalifolia } \\
\text { community }\end{array}$ & $\begin{array}{l}\text { Prostrate dwarf shrubs (Dryas integrifolia, Salix ovalifolia, } \\
\text { S. arctica); forb (Leucanthemum integrifolium); mosses } \\
\text { (Ctenidium procerrimum, Tortula ruralis) }\end{array}$ \\
\hline \multicolumn{3}{|l|}{ Subzone C wd-z } \\
\hline $\begin{array}{l}\text { G3 } \\
\text { Nontussock sedge, } \\
\text { dwarf-shrub, } \\
\text { moss tundra }\end{array}$ & Dryado integrifoliae-Caricetum bigelowii & $\begin{array}{l}\text { Prostrate dwarf-shrubs (Dryas integrifolia, Salix rotundifolia, } \\
\text { S. arctica); sedges (Carex aquatilis, Eriophorum } \\
\text { angustifolium ssp. triste) }\end{array}$ \\
\hline \multicolumn{3}{|c|}{ Subzone D dh-z, fb-d, fb-z, sn-z1, sn-z2 } \\
\hline $\begin{array}{l}\text { B1b } \\
\text { Lichen, forb barren }\end{array}$ & $\begin{array}{l}\text { Junco biglumis-Dryadetum } \\
\text { integrifoliae typicum }\end{array}$ & $\begin{array}{l}\text { Prostrate dwarf shrub (Dryas integrifolia); forb (Saxifraga } \\
\text { oppositifolia); graminoids (Juncus biglumis, Eriophorum } \\
\text { angustifolium spp. triste); moss (Ditrichum flexicaule); } \\
\text { crustose lichens (Polyblastia sendtneri, Lecanora epibryon). }\end{array}$ \\
\hline $\begin{array}{l}\text { P1a } \\
\text { Prostrate dwarf-shrub, } \\
\text { herb tundra }\end{array}$ & $\begin{array}{l}\text { Junco biglumis-Dryadetum } \\
\quad \text { integrifoliae pedicularetosum }\end{array}$ & $\begin{array}{l}\text { Prostrate dwarf shrub (Dryas integrifolia); forbs (Saxifraga } \\
\text { oppositifolia, Polygonum viviparum); sedges (Eriophorum } \\
\text { angustifolium spp. triste, Carex membranacea); mosses } \\
\text { (Hypnum bambergeri, Tomentypnum nitens, } \\
\text { Ditrichum flexicaule, Distichium capillaceum); lichens } \\
\text { (Thamnolia subuliformis, Flavocetraria cucullata, } \\
\text { Lecanora epibryon). }\end{array}$ \\
\hline $\begin{array}{l}\text { G3 } \\
\text { Nontussock sedge, } \\
\text { dwarf- shrub, } \\
\text { moss tundra }\end{array}$ & $\begin{array}{l}\text { Dryado integrifoliae-Caricetum } \\
\text { bigelowii }\end{array}$ & $\begin{array}{l}\text { Prostrate dwarf shrubs (Dryas integrifolia, Salix arctica, } \\
\text { Arctostaphylos rubra, Cassiope tetragona); forb } \\
\text { (Astragalus umbellatus); sedges (Eriophorum angustifolium } \\
\text { spp. triste, Carex bigelowii, Carex membranacea, } \\
\text { Carex scirpoidea); mosses (Tomentypnum nitens, } \\
\text { Hypnum bambergeri, Ditrichum flexicaule). }\end{array}$ \\
\hline \multicolumn{3}{|l|}{ Subzone D fb-w } \\
\hline $\begin{array}{l}\text { B1b } \\
\text { Lichen, forb barren }\end{array}$ & $\begin{array}{l}\text { Junco biglumis-Dryadetum } \\
\text { integrifoliae typicum }\end{array}$ & $\begin{array}{l}\text { Forb (Saxifraga oppositifolia); graminoids } \\
\text { (Juncus biglumis, Eriophorum angustifolium spp. subarcticum, } \\
\text { Juncus triglumis); crustose lichen (Polyblastia sendtneri). }\end{array}$ \\
\hline $\begin{array}{l}\text { W2 } \\
\text { Sedge, moss, } \\
\text { dwarf-shrub wetland }\end{array}$ & $\begin{array}{l}\text { Scorpidium scorpioides-Carex } \\
\text { aquatilis community }\end{array}$ & $\begin{array}{l}\text { Forb (Pedicularis sudetica } \text { spp. albolabiata); sedges } \\
\quad \text { (Eriophorum angustifolium spp. subarcticum, } \\
\quad \text { Carex aquatilis, Carex saxatilis); moss (Scorpidium scorpioides). }\end{array}$ \\
\hline \multicolumn{3}{|c|}{ Subzone E sa-z, hv-d, hv-z, hv-m } \\
\hline $\begin{array}{l}\text { B1c } \\
\text { Liverwort, } \\
\text { moss barren }\end{array}$ & $\begin{array}{l}\text { Anthelia juratzkana-Juncus } \\
\text { biglumis community }\end{array}$ & $\begin{array}{l}\text { Prostrate dwarf-shrub (Vaccinium vitis-idaea); } \\
\text { rush (Luzula arctica); bryophytes (Anthelia juratzkana, } \\
\text { Dicranella subulata, Hylocomium splendens). }\end{array}$ \\
\hline $\begin{array}{l}\text { P1b } \\
\text { Prostrate dwarf-shrub, } \\
\text { herb, moss tundra }\end{array}$ & $\begin{array}{l}\text { Cladino-Vaccinietum vitis-idaea } \\
\text { Racomitrium } \\
\text { lanuginosum var. }\end{array}$ & $\begin{array}{l}\text { Dwarf shrubs (Vaccinium vitis-idaea, Ledum palustre ssp. } \\
\text { decumbens, Betula nana, Empetrum nigrum ssp. } \\
\text { hermaphroditum); forbs (Polygonum bistorta var. } \\
\text { plumosum, Petasites frigidum); grass (Arctagrostis latifolia); } \\
\text { bryophytes(Racomitrium lanuginosum, Dicranum elongatum, } \\
\text { Anastrophyllum minutum, Dicranum spadiceum, } \\
\text { Aulacomnium turgidum); lichens (Cladina arbuscula, } \\
\text { Flavocetraria cucullata, Cladina rangiferina). }\end{array}$ \\
\hline $\begin{array}{l}\text { S1 } \\
\text { Erect dwarf-shrub } \\
\text { tundra }\end{array}$ & $\begin{array}{l}\text { Cladino-Vaccinietum vitis-idaea } \\
\text { Carex bigelowii var. }\end{array}$ & $\begin{array}{l}\text { Dwarf shrubs (Vaccinium vitis-idaea, Ledum palustre ssp. } \\
\text { decumbens, Betula nana, Empetrum nigrum ssp. } \\
\text { hermaphroditum); forbs (Polygonum bistorta var. } \\
\text { plumosum, Petasites frigidum); sedge (Carex bigelowii); } \\
\text { mosses (Hylocomium splendens, Dicranum elongatum, } \\
\text { Aulacomnium turgidum); lichens (Cladina arbuscula, } \\
\text { Cladina rangiferina, Flavocetraria cucullata). }\end{array}$ \\
\hline $\begin{array}{l}\text { G4 } \\
\text { Tussock-sedge, } \\
\text { dwarf-shrub, moss } \\
\quad \text { tundra }\end{array}$ & Sphagno-eriophoretum vaginati & $\begin{array}{l}\text { Dwarf shrubs (Betula nana, Ledum palustre ssp. decumbens, } \\
\text { Salix planifolia spp. pulchra, Vaccinium vitis-idaea, } \\
\text { Cassiope tetragona); forb (Polygonum bistorta var. plumosum); } \\
\text { sedge (Eriophorum vaginatum); mosses (Sphagnum warnstorfii, } \\
\text { Hylocomium splendens, Aulacomnium turgidum); lichens } \\
\text { (Flavocetraria cucullata, Dactylina arctica). }\end{array}$ \\
\hline
\end{tabular}

${ }^{\mathrm{a}}$ From Kade et al. [2005] and Vonlanthen et al. [2008]. Vegetation type abbreviations refer to Circumpolar Arctic Vegetation Map types [Walker et al., 2005]. 
Table 4. Aboveground Plant Biomass Sampled Along a North American Arctic Transect ${ }^{\mathrm{a}}$

\begin{tabular}{|c|c|c|c|c|c|c|c|c|c|c|c|c|}
\hline \multirow[b]{2}{*}{ Grid } & \multicolumn{12}{|c|}{ Biomass of Individual Vegetation Types, $\mathrm{kg} / 100 \mathrm{~m}^{2}$} \\
\hline & Grid Biomass, $\mathrm{kg} / 100 \mathrm{~m}^{2}$ & $\mathrm{~B} 1 \mathrm{a}$ & $\mathrm{B} 1 \mathrm{~b}$ & $\mathrm{~B} 1 \mathrm{c}$ & G1 & $\mathrm{G} 2$ & G3 & G4 & P1a & $\mathrm{P} 1 \mathrm{~b}$ & S1 & W2 \\
\hline is-d & 1.25 & 0 & 0.9 & & 36.9 & & & & & & & \\
\hline is-Z & 17.13 & 0 & 3.9 & & 36.9 & & & & & & & \\
\hline is-m & 23.17 & 1.9 & 16.6 & & 36.8 & & & & & & & \\
\hline mb-d & 9.17 & 0.7 & 10.7 & & & & & & 22.5 & & & \\
\hline $\mathrm{mb}-\mathrm{z}$ & 14.99 & 0 & 5.8 & & & 31.2 & & & & & & \\
\hline gc-d & 14.25 & 0.4 & 6.6 & & & & & & 46.8 & & & \\
\hline gc-z & 30.28 & 0.4 & 6.6 & & & & & & 46.8 & & & \\
\hline gc-m & 27.08 & 0.1 & 6.6 & & & & 41.2 & & & & & 29.1 \\
\hline hi-z & 33.33 & 0.2 & 0.2 & & & & & & 80.9 & & & \\
\hline wd-z & 61.82 & & & & & & 61.8 & & & & & \\
\hline dh-z & 33.17 & & 9.5 & & & & 41.6 & & 18.5 & 18.5 & & 41.6 \\
\hline fb-d & 48.96 & & 4.8 & & & & 62.8 & & 36.2 & & & \\
\hline fb-z & 43.40 & & 4.8 & & & & 48.3 & & 36.2 & 36.3 & & 42.1 \\
\hline $\mathrm{fb}-\mathrm{w}$ & 40.39 & & 11.5 & & & & 48.3 & & 36.3 & & & 42.1 \\
\hline sn-z1 & 44.19 & & 3.7 & & & & 60.9 & & 41.1 & 41.1 & & \\
\hline sn-z2 & 56.30 & & 3.7 & & & & 60.9 & & & 41.1 & & 60.9 \\
\hline sa-z & 75.10 & & & 10.0 & & & & 75.8 & & 48.1 & 73.4 & \\
\hline hv-d & 73.54 & & & 10.0 & & & & 75.6 & & 48.1 & 61.1 & \\
\hline hv-z & 72.08 & & & 10.0 & & & & 75.6 & & 48.1 & 61.1 & \\
\hline hv-m & 73.44 & & & 10.0 & & & & 75.6 & & 48.1 & 61.1 & \\
\hline
\end{tabular}

${ }^{\mathrm{a}}$ Grid biomass for $10 \times 10$-m grids $\left(\mathrm{kg} / 100 \mathrm{~m}^{2}\right)$ are based on relevé biomass of vegetation types multiplied by proportion of vegetation types within each grid (see Figure 7), and biomass density $\left(\mathrm{kg} / 100 \mathrm{~m}^{2}\right.$ ) of individual vegetation types on each grid. See Figure 5 and Table 3 for description of vegetation type codes.

ground plant biomass for all grids ranged from $1.25 \mathrm{~kg} /$ $100 \mathrm{~m}^{2}$ (is-d) to $75.1 \mathrm{~kg} / 100 \mathrm{~m}^{2}$ (sa-z) (Table 4). The combination of plant communities with greater biomass and the increase in between-pattern area from north to south resulted in a fivefold increase in total biomass on the zonal $10 \times 10-\mathrm{m}$ grids from Subzones A and B, to Subzone E (Figure 8a). More information on the biomass of individual Braun-Blanquet plant communities and different plant lifeforms can be found in Walker et al. [2008].

\subsection{Thaw Depth}

[24] Thaw depths varied with bioclimate subzone, increasing from Subzones A to $\mathrm{C}$, and decreasing from Subzone C to E (Figure 8b). Thaw depth increased throughout the growing season, with variance peaking in midsummer. For example, thaw on a Subzone D zonal grid increased from $23 \mathrm{~cm}$ (s.d. 8) in early summer, to $38 \mathrm{~cm}$ (s.d. 10) in mid-summer, to $61 \mathrm{~cm}$ (s.d. 7) in late summer (Figure 9). The dates, means and standard deviations of all thaw measurements collected for the project are in Table S1. In Subzones A and B, August thaw depths were 38 and $54 \mathrm{~cm}$ deep, respectively (Figure $8 \mathrm{~b}$ ) with no significant difference between vegetation types (Table 5). Thaw at the Subzone $\mathrm{C}$ zonal grid was deepest $(86 \mathrm{~cm})$ and was statistically different for the three vegetation communities. Thaw was shallower in Subzone D, $75 \mathrm{~cm}$. The dwarf-shrub vegetation communities had significantly shallower thaw depths than the barren or prostrate-shrub types. Thaw was even shallower in Subzone E $(48 \mathrm{~cm})$, and thaw under the dominant tussock-sedge vegetation was significantly shallower than other vegetation types in the grid (Table 5).

\subsection{Snow Depth}

[25] Snow depths were very similar throughout the northern Arctic (Subzones A, B and C), averaging about $25 \mathrm{~cm}$ (Figure 8c). There were no significant differences between snow depths on different vegetation communities in Subzones A or B (Table 6). Snow was deeper in Subzone D, and snow was significantly shallower on prostrate-shrub vegetation, which occurred on nonsorted circles. Snow was deepest in Subzone E, where less windy conditions allowed the development of a deep, much less dense snowpack. Dwarf-shrub communities on medium-size hummocks had significantly deeper snow than prostrate-shrub on nonsorted circles. The dates, means and standard deviations of all snow depth measurements collected for the project are in Table S2.

\subsection{Moisture Gradient}

[26] Moisture affected the characteristics of patterned ground at all locations. The grids at Franklin Bluffs present an example of the gradient from dry to wet (Figure 10). Both the dry and wet grids had more bare ground than the moist grid. The nonsorted circles were largest in the wet grid. Biomass patterns followed the vegetation patterns. The dry grid had the most biomass $\left(49.0 \mathrm{~kg} / 100 \mathrm{~m}^{2}\right)$, the zonal grid had somewhat less $\left(43.4 \mathrm{~kg} / 100 \mathrm{~m}^{2}\right)$, and the wet grid had the least $\left(40.4 \mathrm{~kg} / 100 \mathrm{~m}^{2}\right)$. Thaw was deepest in the areas and grids with the least vegetation. Average thaw depth was shallowest in the zonal grid $(61 \mathrm{~cm})$, deeper in the dry grid $(63 \mathrm{~cm})$, and deepest in the wet grid $(69 \mathrm{~cm})$. Snow depths were shallowest on the dry grid $(22 \mathrm{~cm})$, deeper on the zonal grid $(37 \mathrm{~cm})$ and deepest on the wet grid $(43 \mathrm{~cm})$, which follows a topographic gradient at that location from a windier bench down to a less-windy abandoned floodplain.

\subsection{Principal Components Analysis}

[27] Principal components analysis created an ordination space accounting for $55 \%$ of the variance in characteristics between grids using two principal components (Figure 11). A total of 8 components were needed to account for $>90 \%$ of the variance between grids. The first component accounted for $37 \%$ of the variation, the second $18 \%$. Additional components accounted for $<10 \%$ each. The first two components had correlations of $r^{2}>0.5$ with many 
a)

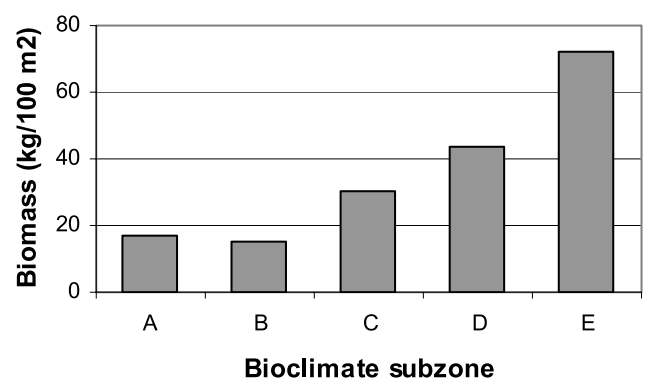

b)

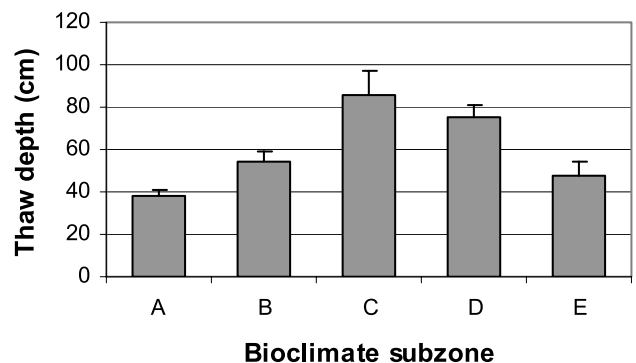

c)

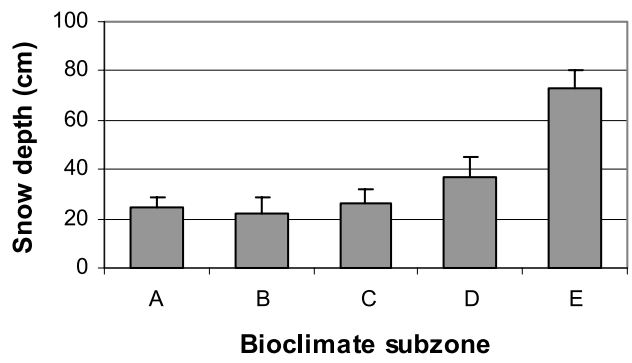

Figure 8. Aboveground plant biomass (a), thaw depth (b) and snow depth (c) on $10 \times 10-\mathrm{m}$ zonal grids in Subzones A-E (is-z, mb-z, gc-z, fb-z, hv-z respectively, except subzone $\mathrm{C}$ snow which is wd-z). Biomass is based on relevé biomass of vegetation communities multiplied by proportion of vegetation communities within each grid. Thaw and snow depths were measured every meter on the grids $(\mathrm{n}=121)$, with standard deviation shown.

environmental factors (Table 7). The first component was very strongly correlated $\left(r^{2}>0.8\right)$ with mean annual surface temperature, aboveground plant biomass, mean annual soil temperature at $0.8 \mathrm{~m}$, and summer warmth index. Additional variables with high correlations included vegetation height, mean annual air tempearature, and moss height. The first component represented a complex gradient of inter-correlated temperature and vegetation characteristics. The second component had $r^{2}$ values $>0.5$ for $\mathrm{pH}$, depth of annual thaw, total soil carbon, \% sand, \% clay and $\mathrm{C}: \mathrm{N}$ ratio. The second component represented a soil characteristics gradient. The third component correlated best with biomass of evergreen shrubs and depth of the A-horizon, but with low $r^{2}$ values $(<0.45)$.

[28] The ordination diagram separated sites in different bioclimate subzones along the $x$ axis (component 1, Figure 11a). The ordination space also segregated the sites by moisture conditions, with dry sites on the left and wet sites in the upper right (Figure 11b). In addition, the ordination grouped the sites by patterned-ground type (Figure 11c). The small nonsorted polygons and hummock sites from Subzones A and B are in the lower left corner, medium-size nonsorted polygons in the upper left, large nonsorted circles in the upper right, medium-size nonsorted circles in the center, and small nonsorted circles in the lower right. The combination of all these factors illustrates the conditions that create each of the different types of patterned ground (Figure 11d).

[29] PCA analysis of the variation in biomass of plant functional types by the environmental variables, found that the first three components accounted for $96 \%$ of the variation in biomass. The environmental variables characterized the vegetation and its biomass very well. The variation between sites, including the patterning, is more complex, and not as thoroughly defined by the PCA analysis using the environmental characteristics sampled.

\section{Discussion}

[30] The maps and analysis of the sites along the North American Arctic Transect illustrate the interactions between the climate, the soil and the vegetation in the creation and perpetuation of small-scale patterned ground. The patterns are similar to those described by Chernov and Matveyeva [1998] in the Russian Arctic. In colder bioclimate subzones, the climate and the soil interact directly and the vegetation has a relatively minor influence. Patterned-ground features are dominated by contraction cracking, forming small nonsorted polygons. Vegetation is unable to colonize much of the ground surface: the top of the soil is dry and crusted, and seeds and plant propagules are blown off, accumulating in the cracks. Growing conditions are less harsh in the cracks, which provide shelter from wind, access to soil moisture, and are the first areas to collect the protective blanket of snow in winter. Even in the most favorable microclimates of these coldest subzones, there are few plant species that can effectively photosynthesize and reproduce due to the low summer temperatures [Bliss and Petersen, 1992]. Plants that are able to grow are low stature and low biomass, forming communities dominated by nonvascular mosses and lichens. In the small nonsorted polygon patterning common in Subzones A and B, the vegetation is too sparse and covers too little of the area to affect thaw depth or snow depth, as demonstrated by the lack of statistical difference between different vegetation types.

[31] In Subzones B and C the vegetation starts to play a larger role in patterned-ground features. The effects are still minimal in areas with small nonsorted polygons, but the small hummocks common in these subzones are a result of the interaction of the vegetation and the soils. Vegetation growing on the tops of the hummocks, particularly mats of the prostrate dwarf shrub, Dryas integrifolia (and the hemiprostrate shrub Cassiope tetragona in snowbeds), trap sediments from fluvial and aeolian erosion [Broll and Tarnocai, 2002]. Examination of the internal morphology of these hummocks revealed many buried, organic-rich layers, representing former hummock surfaces. Radiocarbon dates obtained from these multiple organic-rich layers suggest that each former hummock surface was stable for 100 years 


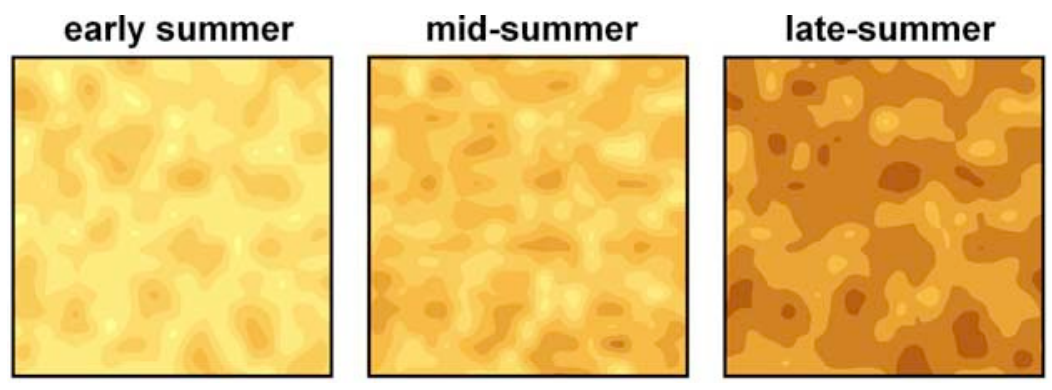

Figure 9. Interpolated thaw depth maps of $10 \times 10-\mathrm{m}$ grid in Subzone D (fb-z), sampled every $0.5 \mathrm{~m}$ on 28 June, 16 July and 25 August 2001. See Figure 5 for legend.

or more and that there was a gradual build-up process in which the age of the organic layers increased with depth. Broll and Tarnocai estimated that a minimum of 1200-2000 years was required for hummocks to develop their present morphologies [Broll and Tarnocai, 2002].

[32] In Subzones C and D, plant communities include more species, especially more vascular plants, including shrubs. The plants are larger, have more biomass and cover more of the ground surface. Their more robust roots stabilize the soil, modify soil moisture by increasing evaporation through plant transpiration and decreasing it through shading of the surface, and modifying the texture and moisture capacity of the soil through added organic material. The vegetation forms a layer between the climate and the soil, insulating the soil from both summer warmth and winter cold. The plants trap snow, increasing the depth of the insulating blanket of snow. However, the effect of thicker vegetation insulating from summer warming outweighs the snow effect, resulting in shallower thaw in areas with more vegetation [Kade et al., 2006]. The cooling effect of vegetation can be seen when comparing the results of this study between centers and edges of patterned-ground features within sites, and when comparing between sites with differing amounts of vegetation.

[33] In Subzones $C$ and D, strong contrasts in vegetation between the centers and margins of patterned ground features create steep local soil-temperature and soil-moisture gradients that result in differential heave and thaw, which in turn create nonsorted circles [Walker et al., 2008]. The lessvegetated centers of nonsorted circles warm earlier in the spring, and have deeper thaw than the surrounding areas throughout the summer, as the dark bare ground warms from the sun. These areas freeze first in the fall, drawing in water from surrounding areas to form ice lenses, which raises the soil surface above the surrounding areas, resulting in differential frost heave [Peterson and Krantz, 2003]. Many plant roots cannot withstand the annual disturbance caused by the creation and melting of these ice lenses. The centers of nonsorted circles are also subject to more disruption due to needle ice formation during fall and spring freeze/ thaw cycles [Kade and Walker, 2008]. The centers of the circles have less insulating snow during the winter due to both differential frost heave and having less vegetation to hold snow. Shallower snow cover is an additional factor making the centers less favorable microsites for vegetation growth: any vegetation protruding above the snow is subject to wind damage, desiccation, and herbivory. These interactions reinforce the patterned-ground features, minimizing colonization of the centers of the circles. The nonpatterned areas around the circles form even more of a contrast than in colder subzones, as they support continuous sedge, dwarfshrub vegetation that often includes a thick moss layer.

[34] In the warmest subzones of the Arctic, plant growth is vigorous enough to overcome most of the disturbance effects of frost heave, and vegetation is able to grow over most patterned-ground features. The controlling effect of vegetation on patterned ground features is demonstrated by the contrast between two locations in Subzones D and E (Sagwon Nonacidic and Sagwon Acidic). These two locations are within $2 \mathrm{~km}$ of each other, and have similar climates and soil textures. The Subzone E location has thicker moss layers, thicker organic soil horizons, a taller plant canopy, and greater biomass. The effect of the vegetation on the soil thermal properties is to substantially reduce thaw depths and soil heave. The Subzone E location also has much less cover of bare ground and patternedground vegetation types, to the point that patterned-ground features are not evident to the casual observer.

[35] The effect of vegetation on soil thermal properties was also illustrated by a vegetation transplant experiment at

Table 5. Mean Mid-July Thaw Depth Within $10 \times 10-\mathrm{m}$ Grid by Vegetation Type, Sampled Along a North American Arctic Transect ${ }^{\mathrm{a}}$

\begin{tabular}{|c|c|c|c|c|c|c|c|c|c|}
\hline \multirow[b]{2}{*}{ Vegetation Type } & \multicolumn{9}{|c|}{ Thaw Depth, cm } \\
\hline & B1a & $\mathrm{B} 1 \mathrm{~b}$ & $\mathrm{~B} 1 \mathrm{c}$ & G1 & P1a & P1b & W2 & G4 & S2 \\
\hline Subzone A & 30.82 & 30.25 & & 30.83 & & & & & \\
\hline Subzone B & 28.16 & 28.37 & & & 28.41 & & & & \\
\hline Subzone C & 60.73(a) & $58.60(\mathrm{~b})$ & & & $56.79(\mathrm{c})$ & & & & \\
\hline Subzone D & & 46.01(a) & & & 44.72(a) & 43.93(a) & 27.09(b) & 35.81(b) & \\
\hline Subzone E & & & 40.09(a) & & $36.18(\mathrm{ac})$ & $24.84(\mathrm{bc})$ & & $15.11(\mathrm{~d})$ & $23.77(\mathrm{ac})$ \\
\hline
\end{tabular}

${ }^{a}$ Interpolated sample thaw points were compared to vegetation mapping. Significance tested using sample point data, t-test with Bonferroni's correction. No significant differences in Subzones A or B. See Figure 5 and Table 3 for description of vegetation type codes. 
Table 6. Mean Snow Depth Within $10 \times 10-\mathrm{m}$ Grid by Vegetation Type, Sampled Along a North American Arctic Transect ${ }^{\mathrm{a}}$

\begin{tabular}{|c|c|c|c|c|c|c|c|c|c|}
\hline \multirow[b]{2}{*}{ Vegetation Type } & \multicolumn{9}{|c|}{ Snow Depth, cm } \\
\hline & B1a & $\mathrm{B} 1 \mathrm{~b}$ & $\mathrm{~B} 1 \mathrm{c}$ & G1 & P1a & $\mathrm{P} 1 \mathrm{~b}$ & W2 & G4 & S1 \\
\hline Subzone A & 26.30 & 27.52 & & 26.58 & & & & & \\
\hline Subzone B & 20.72 & 22.02 & & & 22.18 & & & & \\
\hline Subzone C & NA & NA & & NA & & & & & \\
\hline Subzone D & & $35.66(a)$ & & & 31.79(b) & $35.55(\mathrm{ab})$ & $40.83^{\mathrm{b}}$ & 37.58(a) & \\
\hline Subzone E & & & $69.27^{\mathrm{b}}$ & & $69.00^{\mathrm{b}}$ & $70.12(a)$ & & $72.68(\mathrm{ab})$ & $72.00(\mathrm{~b})$ \\
\hline
\end{tabular}

${ }^{a}$ Interpolated sample snow points were compared to vegetation mapping. Significance tested using sample point data, t-test with Bonferroni's correction. No significant differences in Subzones A or B. See Figure 5 and Table 3 for description of vegetation type codes.

${ }^{\mathrm{b}}$ One or no data points in this vegetation type.

the Sagwon Nonacidic location [Kade and Walker, 2008]. The removal of vegetation from the nonsorted circles at this location resulted in a $1.4^{\circ} \mathrm{C}$ increase in the mean summer soil surface temperature when compared to the controls, a $6 \%$ increase in the thaw depth, and a $26 \%$ increase in the amount of frost heave. The opposite effect occurred when a 10 -cm thick layer of moss was transplanted onto the circles, resulting in a $2.8^{\circ} \mathrm{C}$ decrease in the mean summer soil temperature, a $15 \%$ reduction in the thaw layer, and $52 \%$ decrease in the heave [Kade and Walker, 2008].
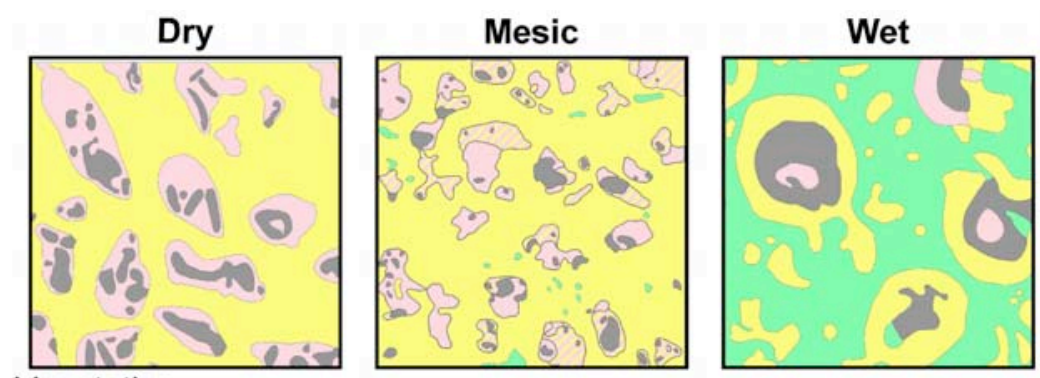

Vegetation
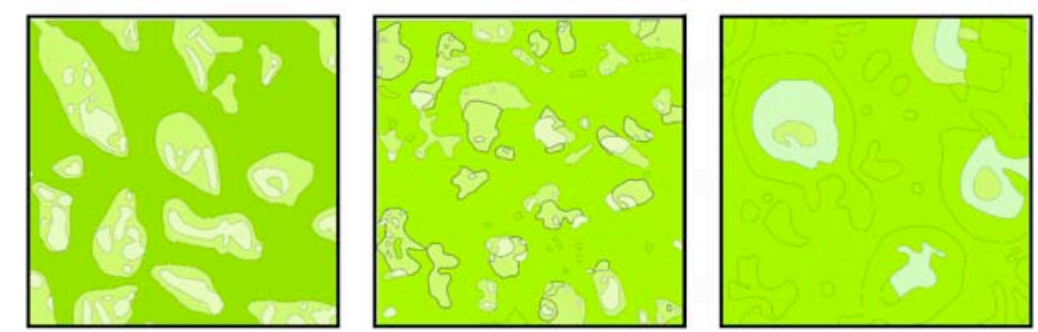

\section{Biomass}
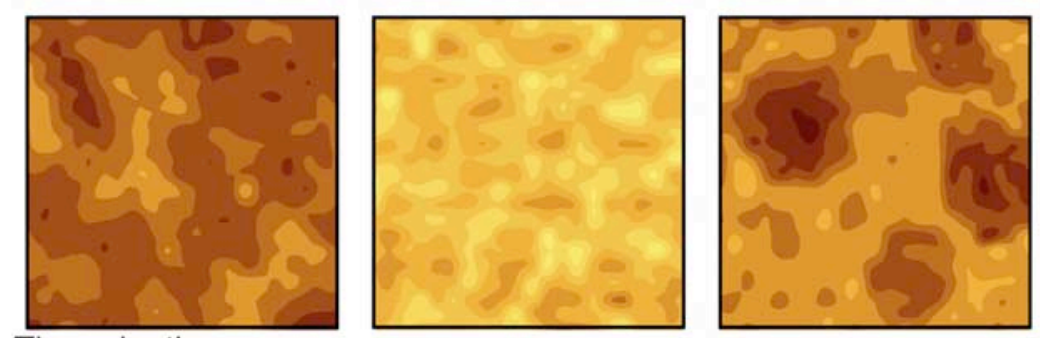

Thaw depth
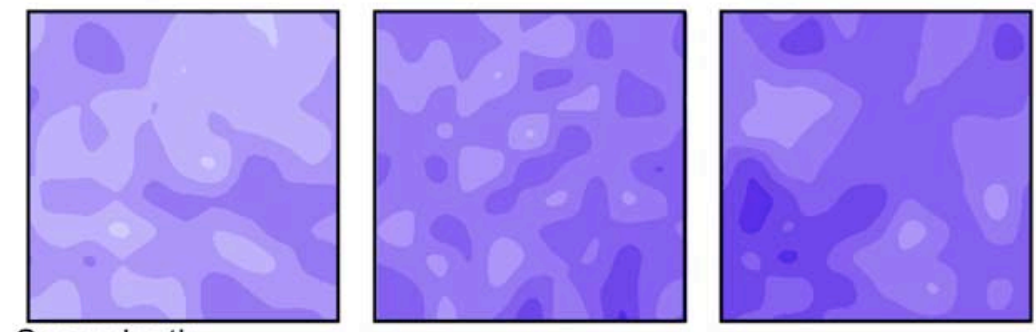

Snow depth

Figure 10. Maps of vegetation, biomass, July thaw depth, and end-of-season snow depth on dry, zonal and wet $10 \times 10-\mathrm{m}$ grids in Subzone D (fb-d, fb-z, fb-w). See Figure 5 for legend. 
(a)

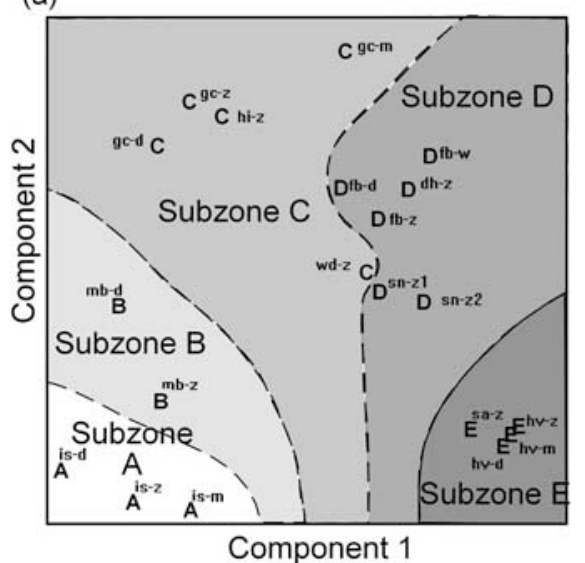

(c)

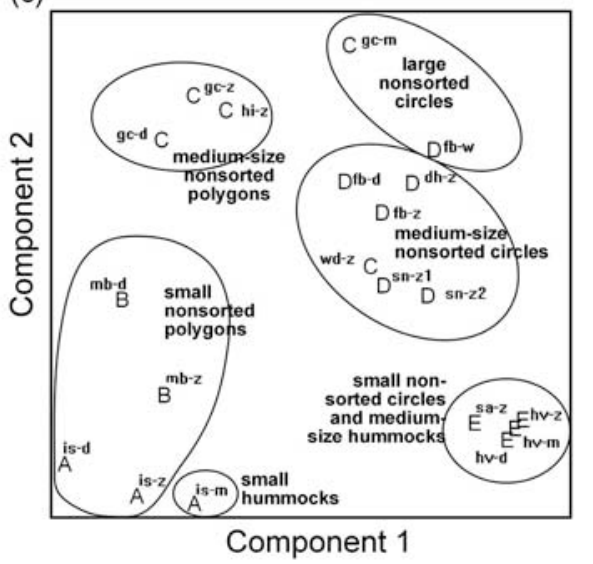

(b)

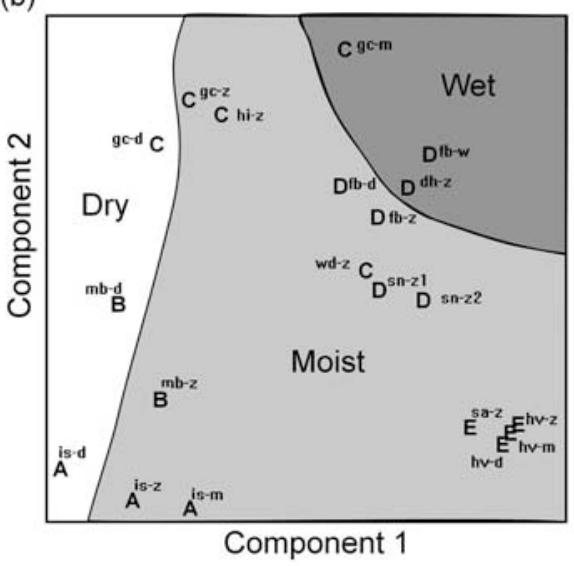

(d)

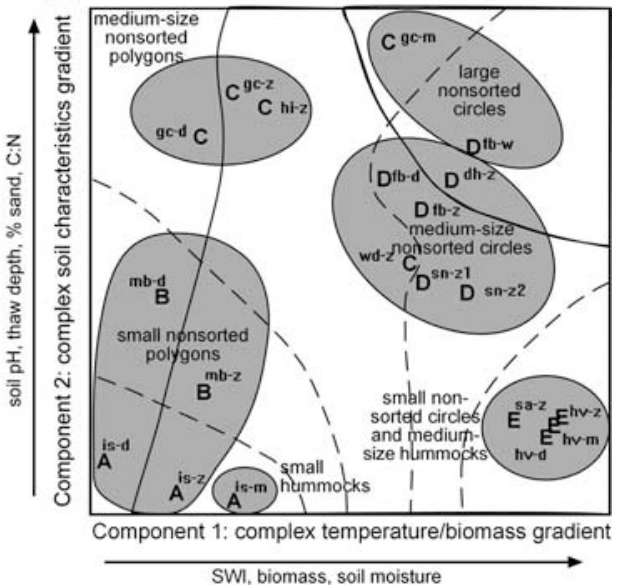

Figure 11. Ordination created by Principal Components Analysis (PCA) of 20 grids, with different characteristics of grids shown on ordination space created by first two components: (a) tundra bioclimate subzones, (b) site moisture, (c) patterned ground type, and (d) combination of subzones, moisture and patterned ground type.

Table 7. Correlation Coefficients (r2) for Variables With Highest Correlations in Principal Components Analysis Ordination of Twenty $10 \times 10-\mathrm{m}$ Grids Along a North American Arctic Transect

\begin{tabular}{lccr}
\hline & Axis 1 & Axis 2 & Axis 3 \\
\hline Mean annual surface temperature & $\mathbf{0 . 8 4 4}$ & 0.001 & 0.011 \\
Aboveground plant biomass & $\mathbf{0 . 8 4 0}$ & 0.023 & 0.028 \\
Mean annual soil temperature $(0.8 \mathrm{~m})$ & $\mathbf{0 . 8 3 9}$ & 0 & 0.013 \\
Summer warmth index & $\mathbf{0 . 8 0 0}$ & 0.033 & 0.079 \\
Vegetation height & $\mathbf{0 . 7 6 6}$ & 0.067 & 0.018 \\
Mean annual air temperature & $\mathbf{0 . 7 6 0}$ & 0.076 & 0.038 \\
Moss height & $\mathbf{0 . 7 3 2}$ & 0.143 & 0.043 \\
Surface micro-relief & $\mathbf{0 . 6 9 9}$ & 0.113 & 0.155 \\
Volumetric soil moisture & $\mathbf{0 . 6 8 0}$ & 0.002 & 0.141 \\
Snow depth & $\mathbf{0 . 6 3 4}$ & 0.152 & 0.002 \\
Differential frost heave & $\mathbf{0 . 5 6 9}$ & 0.034 & 0 \\
O-horizon thickness & $\mathbf{0 . 5 4 5}$ & 0.030 & 0.264 \\
Cover of deciduous shrubs & $\mathbf{0 . 5 4 3}$ & 0.043 & 0.064 \\
Soil pH & 0.045 & $\mathbf{0 . 6 8 9}$ & 0.003 \\
Depth of annual thaw & 0.008 & $\mathbf{0 . 6 2 3}$ & 0.017 \\
Total soil carbon & 0.063 & $\mathbf{0 . 6 1 8}$ & 0 \\
\% sand & 0.006 & $\mathbf{0 . 5 4 4}$ & 0.059 \\
\% clay & 0.165 & $\mathbf{0 . 5 0 2}$ & 0.005 \\
C/N ratio in soil & 0.019 & $\mathbf{0 . 5 0 1}$ & 0.005 \\
Cover of evergreen shrubs & 0.224 & 0.071 & 0.432 \\
\hline
\end{tabular}

[36] Medium-size hummocks occur in Subzone E and the northern boreal forest, formed by the aggradation of ice at the permafrost boundary. Unlike the ice in nonsorted circles that causes differential heave, this ice does not melt annually. A conceptual model proposed by Y. Shur starts with thermal contraction cracks that are spaced at $1-3 \mathrm{~m}$, the spacing of medium-size nonsorted polygons [Shur and Ping, 2003]. Colonization of the cracks by mosses and lichens gradually causes a cooler soil thermal regime and a reduced active layer beneath the cracks compared to the polygon centers, as described above. This leads eventually to the development of nonsorted circles and a bowl-shaped permafrost table beneath the circles, as a result of differential thawing caused by differences in plant cover on barren circles versus well-vegetated inter-circle areas. Over time, as vegetation colonizes (and insulates) the once barren soils, the permafrost table aggrades (moves upward and inward toward the center of the bowl), which forces the soils in the center of the circles radially inward and upward forming the hummocks [Kokelj et al., 2007]. The importance of the vegetation in maintaining the soil ice and the structure of these medium-size hummocks is demonstrated by the fact 
that hummocks collapsed after vegetation was burned by a wildfire, and re-formed as the vegetation recovered [Kokelj et al., 2007]. Experimental manipulations simulating the insulative effects of vegetation produced similar results, with increased hummock height resulting from added insulation, and decreased height from removal of insulating vegetation [Kokelj et al., 2007].

[37] Moisture affects patterned ground by influencing both the vegetation and the soil properties. Less vegetation grows on wet sites than moist sites or dry sites. Wet sites also have larger patterns, with a greater proportion of bare areas than moist sites, and a stronger contrast between soil types in the bare areas and the surrounding vegetated areas. Shrubs and mosses are less common than in moist areas. The increase in bare ground, decrease in albedo, and decrease in vegetation insulation leads to deeper thaw at wet sites, and greater differential frost heave. As a result, nonsorted circles in wet areas are often very dramatic, with large barren centers, outlined by a ring of drier vegetation which has been pushed into a raised rim by the annual heave of the center of the circle, both of which contrast strongly with the surrounded wet sedge vegetation.

\section{Conclusions}

[38] Consistent trends in pattern size, pattern type, vegetation characteristics, biomass, thaw depth and snow depth were evident along bioclimate and moisture gradients. From the northern to southern end of the North American Arctic Transect, patterns changed from small nonsorted polygons $(10-30 \mathrm{~cm})$, to nonsorted circles (the largest about $3 \mathrm{~m}$ diameter). Nonsorted circles were more common and larger in wetter sites than in drier sites. Vegetation increased from north to south in amount of cover, dominance of vascular plants, height of vegetation, and abundance and vertical growth form of shrubs. Biomass followed similar trends, with a fivefold increase from Subzones A-E from about 15 to over $70 \mathrm{~kg} / 100 \mathrm{~m}^{2}$. Thaw depth increased from Subzones A $(<40 \mathrm{~cm})$ to $C(>80 \mathrm{~cm})$, but then decreased from Subzones $C$ to $E(<50 \mathrm{~cm})$ as the vegetation increasingly insulated the soil. Thaw depths were deeper in a dry and wet grid in Subzone D, which both had more bare ground than a better-vegetated zonal grid in the same area. There was a threefold increase in snow depth along the climate gradient, from Subzones A$\mathrm{C}$, which had $<25 \mathrm{~cm}$ of snow, to $>70 \mathrm{~cm}$ of snow in Subzone E.

[39] Principal components analysis showed how the climate, vegetation and soils together characterize patternedground features. Climate and vegetation characteristics formed the strongest component, and soil characteristics formed the second component. Small nonsorted polygons are found in Subzones A and B, with little vegetation and dry soils. The interaction between the soils and the climate is dominant. Vegetation grows in protected areas, but has little influence on soil or snow characteristics. Medium-size nonsorted polygons are found in drier areas and large nonsorted circles in wetter areas of Subzone C. Climate plays a strong role in controlling patterning in Subzone C, but so does vegetation. The contrast between vegetated and nonvegetated areas is strongest in Subzone C. Cryoturbation limits plant colonization, resulting in less biomass in centers of circles, deeper thaw in summer, and shallower snow in winter.

[40] Medium-size nonsorted circles are common in moist areas in Subzone D, with large nonsorted circles in wet areas. Differences in soil temperature between the centers and the edges of the circles create differential heave. In Subzone E vegetation growth is robust enough to colonize almost all bare ground, insulating the soil more uniformly and masking patterned ground features. Nonsorted circles can still be recognized by their different vegetation, deeper thaw, and shallower snow due to differential frost heave.

[41] Acknowledgments. Thanks to Joseph Bickley, Ronnie Daanen, Jamie Hollingsworth, Lindsey Kiesz, Julie Knudsen, Patrick Kuss, Hilmar Maier, Christine Martin, Dmitri Nicolski, Eamon O'Regan, Vladimir Romanovsky, Bhaskar Candra Sahoo, Nathan Shoutis, Jan Tomsen, and Ina Timling who helped collect thaw and snow depth data. Two anonymous reviewers provided comments that were helpful in improving the manuscript's organization and focus. This project was funded by Biocomplexity: NSF grant OPP-0120736, Greening of the Arctic (NSF SASS): ARC0531180, Greening of the Arctic (NASA LCLUC): NNG6GE00A.

\section{References}

Ballantyne, C. K. (1996), Formation of miniature sorted patterns by shallow ground freezing: a field experiment, Permafrost Periglac. Proc., 7, 409424, doi:10.1002/(SICI) 1099-1530(199610)7:4<409::AID-PPP230> 3.0. $\mathrm{CO} ; 2-3$.

Bliss, L. C., and K. M. Petersen (1992), Plant succession, competition and the physiological constraints of species in the high arctic, in Arctic ecosystems in a changing climate: an ecophysiological perspective, edited by F. S. I. Chapin et al., pp. 111-136, Academic Press, Inc., San Diego, CA.

Broll, G., and C. Tarnocai (2002), Turf hummocks on Ellesmere Island, Canada, paper presented at Transactions of the 17th World Congress of Soil Science, 14-21 August 2002, Bangkok, Thailand.

Brown, J., K. M. Hinkel, and F. E. Nelson (2000), The Circumpolar Active Layer Monitoring (CALM) program: research designs and initial results, Polar Geogr., 24, 165-258.

CAVM Team (2003), Circumpolar Arctic Vegetation Map, scale 1: 7500 000, U. S. Fish and Wildlife Service, Anchorage, Alaska.

Chernov, Y. I., and N. V. Matveyeva (1998), Arctic ecosystems in Russia, in Polar and alpine tundra, edited by F. E. Wielgolaski, pp. 361-507, Elsevier, Amsterdam.

Elvebakk, A. (1999), Bioclimate delimitation and subdivisions of the Arctic, in The Species Concept in the High North-A Panarctic Flora Initiative, edited by I. Nordal and V. Y. Razzhivin, pp. 81-112, The Norwegian Academy of Science and Letters, Oslo.

Kade, A. N., and D. A. Walker (2008), Experimental alteration of vegetation on nonsorted circles: effects on cryogenic activity and implications for climate change in the Arctic, Arct. Antarct. Alp. Res, 40, 96-103.

Kade, A. N., D. A. Walker, and M. K. Raynolds (2005), Plant communities and soils in cryoturbated tundra along a climate gradient in the Low Arctic, Alaska, Phytocoenologia, 35, 761-820, doi:10.1127/0340269X/2005/0035-0761.

Kade, A. N., V. E. Romanovsky, and D. A. Walker (2006), The $n$-factor of nonsorted circles along a climate gradient in arctic Alaska, Permafrost Periglac. Proc., 17, 279-289, doi:10.1002/ppp.563.

Kokelj, S., C. R. Burn, and C. Tarnocai (2007), The structure and dynamics of earth hummocks in the subarctic forest near Inuvik, Northwest Territories, Canada, Arct. Antarct. Alp. Res., 39, 99-109, doi:10.1657/ 1523-0430(2007)39[99:TSADOE]2.0.CO;2.

Lachenbruch, A. H. (1962), Mechanics of thermal contraction cracks and ice-wedge polygons in permafrost, Spec. GSA Pap., 70, 1-69.

Matveyeva, N. V. (1998), Zonation in arctic vegetation cover, 220 pp., Proceedings of the Komarov Botanical Institute, Issue 21. Russian Academy of Sciences, St. Petersburg (in Russian).

McCune, B., and J. Grace (2002), Analysis of ecological communities, 300 pp., MjM Software Design, Gleneden Beach, Oregon.

McCune, B., and M. J. Mefford (1999), PC-ORD, Multivariate analysis of ecological data, Version 4 for Windows, 237 pp., MjM Software Design, Gleneden Beach, Oregon.

Molau, U., and P. Molgaard (1996), ITEX Manual, 2nd ed., Danish Polar Center, Copenhagen.

National Research Council (2004), A Vision for the International Polar

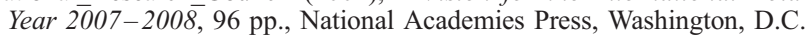


Peterson, R. A., and W. B. Krantz (2003), A mechanism for differential frost heave and its implications for patterned-ground formation, J. Glac., 49, 69-80.

Razzhivin, V. Y. (1999), Zonation of vegetation in the Russian Arctic, in The Species Concept in the High North - A Panarctic Flora Initiative, edited by I. Nordal and V. Y. Razzhivin, pp. 113-130, The Norwegian Academy of Science and Letters, Oslo.

Shur, Y., and M. T. Jorgenson (2007), Patterns of permafrost formation and degradation in relation to climate and ecosystems, Permafrost Periglac. Proc., 18, 7-19.

Shur, Y., and C. L. Ping (2003), The driving force of frost boil and hummock formation, Eos Trans. AGU, 84, Abstract C21B-0823.

Vonlanthen, C. M., D. A. Walker, M. K. Raynolds, H. P. Kuss, F. J. A. Daniels, and N. V. Matveyeva (2008), Patterned-ground plant communities along a bioclimate gradient in the High Arctic, Canada, Phytocoenologia, in press.

Walker, D. A. (1972), The analysis of the effectiveness of a television scaning densitometer for indicating geobotanical features in an ice-wedge polygon complex at Barrow, Alaska, 129 pp., University of Colorado, Boulder, $\mathrm{CO}$.
Walker, D. A., et al. (2004), Frost-boil ecosystems: complex interactions between landforms, soils, vegetation, and climate, Permafrost Periglac. Proc., 15, 171-188, doi:10.1002/ppp.487.

Walker, D. A., et al. (2005), The Circumpolar Arctic Vegetation Map, J. Veg. Sci., 16, 267-282, doi:10.1658/1100-9233(2005)016[0267:TCAVM] 2.0.CO;2.

Walker, D. A., et al. (2008), Arctic patterned-ground ecosystems: a synthesis of studies along a North American Arctic Transect, J. Geophys. Res., doi:10.1029/2007JG000504, in press.

Washburn, A. L. (1980), Geocryology: A Survey of Periglacial Processes and Environments, 406 pp., Halsted Press, John Wiley and Sons, New York.

A. N. Kade, C. A. Munger, M. K. Raynolds, and D. A. Walker, Institute of Arctic Biology, University of Alaska Fairbanks, 311 Irving, P.O. Box 757000, Fairbanks, AK 99775, USA. (anja_kade@yahoo.com; fncam1@ uaf.edu; fnmkr@uaf.edu; ffdaw@uaf.edu)

C. M. Vonlanthen, Plant Science Center, ETH Zurich, 8092 Zurich, Switzerland. (cvonlanthen@ethz.ch) 